Review

\title{
Illumination of the Spatial Order of Intracellular pH by Genetically Encoded pH-Sensitive Sensors
}

\author{
Mojca Benčina ${ }^{1,2}$ \\ 1 Laboratory of Biotechnology, National Institute of Chemistry, 1000 Ljubljana, Slovenia \\ 2 Center of Excellence EN-FIST, 1000 Ljubljana, Slovenia; E-Mail: mojca.bencina@ki.si; \\ Tel.: +386-1-4760-334; Fax: +386-1-4760-300
}

Received: 12 November 2013; in revised form: 27 November 2013 / Accepted: 27 November 2013 / Published: 5 December 2013

\begin{abstract}
Fluorescent proteins have been extensively used for engineering genetically encoded sensors that can monitor levels of ions, enzyme activities, redox potential, and metabolites. Certain fluorescent proteins possess specific $\mathrm{pH}$-dependent spectroscopic features, and thus can be used as indicators of intracellular $\mathrm{pH}$. Moreover, concatenated $\mathrm{pH}$-sensitive proteins with target proteins pin the $\mathrm{pH}$ sensors to a definite location within the cell, compartment, or tissue. This study provides an overview of the continually expanding family of $\mathrm{pH}$-sensitive fluorescent proteins that have become essential tools for studies of $\mathrm{pH}$ homeostasis and cell physiology. We describe and discuss the design of intensity-based and ratiometric $\mathrm{pH}$ sensors, their spectral properties and $\mathrm{pH}$-dependency, as well as their performance. Finally, we illustrate some examples of the applications of $\mathrm{pH}$ sensors targeted at different subcellular compartments.
\end{abstract}

Keywords: $\mathrm{pH}$ homeostasis; intensity-based $\mathrm{pH}$-sensitive sensor; ratiometric transgene $\mathrm{pH}$ indicator; flow cytometry; microscopy

\section{Introduction}

The regulation and homeostasis of $\mathrm{pH}$ within a cell and its subcellular compartments are crucial for the viability of any living cell, from the simplest prokaryotes to complex multicellular organisms. Stringent $\mathrm{pH}$ requirements are necessary for efficient metabolism, protein stability, ion channel activity, membrane trafficking, protein sorting, and proteolytic processing of proteins. Cellular compartments are protected from rapid, local changes in $\mathrm{pH}$ by intrinsic buffering capacity that is provided by various intracellular weak acids and bases. A more dynamic network for controlling 
intracellular $\mathrm{pH}\left(\mathrm{pH}_{\mathrm{i}}\right)$ is $\mathrm{pH}$ homeostasis, which is composed of an ensemble of well-coordinated ion carriers, such as ion permeable channels, transporters, and pumps [1-4].

An important step forward in the understanding $\mathrm{pH}$ homeostasis has been achieved with the development of genetically encoded fluorescent $\mathrm{pH}$-sensitive sensors, which provide a means for spatial and temporal imaging of $\mathrm{pH}$ dynamics. Fluorescent proteins (FPs) as intrinsic intracellular reporters have many advantages over conventional fluorescent dyes in live cell imaging. They are genetically encoded, therefore, no loading of dye is necessary, thereby enabling noninvasive imaging. The FPs can be precisely targeted to almost any organelle, compartment, or tissue. Moreover, FPs have been designed to respond to a greater variety of biological events and signals than conventional dyes. The sensors based on FPs have been used in living cells to report cellular concentrations of ions, second messengers cAMP and inositol phosphates, ATP, redox potential, reactive oxygen species, enzyme activities, and $\mathrm{pH}$ (review [5]).

Figure 1. (A) A two state model of $\mathrm{pH}$ dependent ground states of wtGFP. Four molecules of water and side-chains of amino acids depicted in grey are involved in hydrogen-bonding with the chromophore. (B) Chromophore formation involves cyclization, imidazolinone ring system formation, dehydration and oxidation.
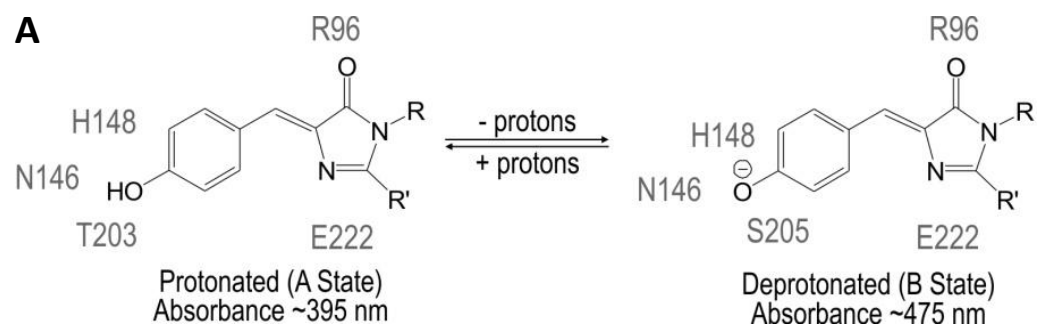

B

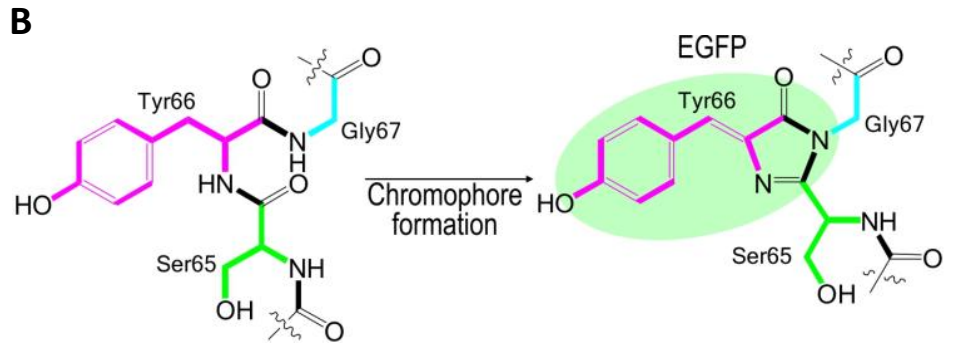

The use of FPs began with the identification and subsequent characterization of wild-type green fluorescent protein (wtGFP) from the jellyfish Aequorea victoria [5,6]. Within the $\beta$-barrel structure of GFP, three consecutive amino acids S65, Y66, G67 form by post-translational cyclization a chromophore that, by itself, is not fluorescent. Amino acids Q69, Q94, R96, H148, T203, S205, and E222 that are placed around the chromophore are necessary for GFP fluorescence [7]. These residues function as proton donors and acceptors and define spectral and photophysical properties of GFPs [8]. Bizzarri et al. [9] provide a detailed review of the physical and chemical characteristics of the chromophores of different GFP mutants. Briefly, the optical properties of protonated-neutral and deprotonated-anionic states differ among FPs. Among other parameters, pH also affects the equilibrium between protonated and deprotonated forms. Some FPs show pH-dependent absorption/ 
fluorescence spectra in the physiological $\mathrm{pH}$ range and are, therefore, used as $\mathrm{pH}$ sensors for live cell imaging (Figure 1).

Further, pH-sensitive FPs are divided in two groups: (i) intensity-based sensors and (ii) ratiometric $\mathrm{pH}$-sensitive proteins with dual excitation and/or emission spectra. There is also a third group of $\mathrm{pH}$-sensitive proteins-chimeric proteins, which are concatenated $\mathrm{pH}$-sensitive FPs with another fluorescent or luminescent protein that gain novel $\mathrm{pH}$-dependent spectral properties through fusion. Some of the most frequently used $\mathrm{pH}$ sensors are described below.

\section{Intensity-Based pH Indicators}

The protonated state of the wtGFP absorbs at $395 \mathrm{~nm}$ and emits at $508 \mathrm{~nm}$, while the deprotonated state absorbs at $475 \mathrm{~nm}$ and emits at $503 \mathrm{~nm}$ [9]. The neutral, protonated state is progressively converted to the anionic, deprotonated state as the $\mathrm{pH}$ increases. The so-called intensity-based, nonratiometric $\mathrm{pH}$ sensors possess good $\mathrm{pH}$ responsiveness, but are characterized by very poor emission from the neutral chromophore (395-nm excitation). Due to the rather complex calibration of the intensity-based $\mathrm{pH}$ sensors, they are usually used to report changes in $\mathrm{pH}_{\mathrm{i}}$ rather than $\mathrm{pH}_{\mathrm{i}}$ itself. Many variations of $\mathrm{pH}$-sensitive FPs have been created with random and targeted mutagenesis of the Aequorea wtGFP [5] or the Discosoma mRFP [10]. These FPs differ in terms of apparent $\mathrm{pK}_{\mathrm{a}}$ that defines an operational $\mathrm{pH}$ range of the sensor and by excitation/emission spectra that delineate the equipment used for analysis (Table 1).

Kneen et al. [11] were among the first to explore the possibility that the GFP could be used as a $\mathrm{pH}$ sensor in living cells. They synthesized four green GFP mutants with $\mathrm{pK}_{\mathrm{a}}$ values 6.0 (EGFP, GFP-F64L/ S65T), 5.9 (S65T), 6.1 (Y66H), and 4.8 (T203I). The absorbance and emission spectra of two S65T mutants are similar to that of the wtGFP with two absorption maxima at 390 and $490 \mathrm{~nm}$, with the only excitation wavelength at $490 \mathrm{~nm}$ and emission at $>510 \mathrm{~nm}$. To evaluate the suitability of enhanced GFP (EGFP) as a pH sensor in living cells, the EGFP was expressed in cytosol, mitochondria, Golgi, and the endoplasmic reticulum of CHO and LLC-PK1 cells. Two other mutants (Y66H and T203I) have blue-shifted spectra with single maxima and parallel $\mathrm{pH}$-dependent changes in absorbance and fluorescence [11]. In the same year, another blue-shifted $\mathrm{pH}$ sensitive protein was synthesized. Extensive mutagenesis of wtGFP generated an enhanced cyan GFP (ECFP); its absorption and emission spectra peak at $440 \mathrm{~nm}$ and $480 \mathrm{~nm}$, respectively, with $\mathrm{pK}_{\mathrm{a}} 6.4$ [12].

Independent of Kneen et al., Miesenbock et al. [13] generated a GFP mutant-termed ecliptic pHluorin —with $\mathrm{pK}_{\mathrm{a}}$ 7.1. Substitutions S147D, N149Q, T161I, S202F, Q204T, and A206T on wtGFP provoked a reduction in $395 \mathrm{~nm}$ excitation and an increase in $475 \mathrm{~nm}$ excitation, which is induced by a pH shift. During acidification, the e-pHluorin gradually loses fluorescence. The e-pHluorin is widely used for imaging vesicle fusion events because it is nonfluorescent at a $\mathrm{pH}$ lower than 6 at $475 \mathrm{~nm}$ excitation, but still weakly seen at $395 \mathrm{~nm}$. A brighter version of the e-pHluorin, a superecliptic pHluorin (e $\mathrm{e}_{\mathrm{s}}$-pHluorin) [14] contains two additional mutations, F64L and S65T, in the original ecliptic pHluorin, thereby leading to enhanced fluorescence with similar absorption/emission spectra. These two mutations are also characteristic of EGFP [11]. A plant ecliptic pHluorin-PEpHluorin [4] —is a fusion between a soluble-modified GFP (smGFP) [15] with F99S mutation and e-pHluorin with 
additional mutations M153T and V163A [4]. The presence of smGFP decreases $\mathrm{pK}_{\mathrm{a}}$ to 6.0 with an acidification-dependent decrease at excitation peaks $395 \mathrm{~nm}$ and $475 \mathrm{~nm}$, recorded at $512 \mathrm{~nm}$.

Table 1. Intensity-based $\mathrm{pH}$-sensitive fluorescent proteins.

\begin{tabular}{|c|c|c|c|c|c|c|}
\hline & \multirow{2}{*}{$\mathbf{p} \mathbf{K}_{\mathbf{a}}$} & $\lambda_{\mathrm{x} 1}(\mathrm{~nm})$ & $\lambda_{x 2}(\mathrm{~nm})$ & \multirow{2}{*}{$\lambda_{\mathrm{e}}(\mathrm{nm})$} & \multirow{2}{*}{$\begin{array}{l}\text { Quantum } \\
\text { Yield }\end{array}$} & \multirow{2}{*}{ Reference } \\
\hline & & \multicolumn{2}{|c|}{$\varepsilon\left(\mathbf{m M}^{-1} \cdot \mathbf{c m}^{-1}\right)$} & & & \\
\hline \multicolumn{7}{|c|}{ Green FP } \\
\hline $\begin{array}{l}\text { ECFP (GFP-K26R, F64L, S65T, Y66W, } \\
\text { N146I, M153T, V163A, N164H, H231L) }\end{array}$ & 6.4 & b & $\begin{array}{c}440 \\
33\end{array}$ & 480 & 0.40 & [12] \\
\hline $\begin{array}{c}\text { EGFP } \\
(\text { GFP-F64L, S65T, H231L) }\end{array}$ & 5.8 & $\begin{array}{c}396^{\mathrm{a}} \\
29\end{array}$ & $\begin{array}{c}489 \\
60\end{array}$ & 509 & 0.60 & {$[11,12]$} \\
\hline $\begin{array}{c}\text { Ecliptic pHluorin (GenBank: AF058695) } \\
\text { (GFP-S147D, N149Q, T161I, V163A, } \\
\text { S175G, S202F, Q204T, A206T) }\end{array}$ & 7.1 & $396^{\mathrm{a}}$ & 476 & 508 & $\mathrm{~b}$ & [13] \\
\hline $\begin{array}{c}\text { Superecliptic pHluorin (GenBank: AY533296) } \\
\text { (e-pHluorin-F64L, S65T) }\end{array}$ & 7.2 & $396^{\mathrm{a}}$ & 476 & 508 & $\mathrm{~b}$ & [14] \\
\hline PEpHluorin & $\mathrm{b}$ & $395^{\mathrm{a}}$ & 475 & 512 & b & {$[4]$} \\
\hline $\begin{array}{c}\text { mWasabi } \\
\text { (GenBank: EU024648) }\end{array}$ & 6.5 & $\mathrm{~b}$ & $\begin{array}{c}493 \\
90\end{array}$ & 509 & 0.80 & [16] \\
\hline \multicolumn{7}{|c|}{ Yellow FPs } \\
\hline $\begin{array}{c}\text { EYFP } \\
\text { (GFP-F64L, S65G, S72A, T203Y, H231L) }\end{array}$ & 7.1 & $390^{\mathrm{a}}$ & $\begin{array}{c}514 \\
84\end{array}$ & 527 & 0.61 & {$[12,17]$} \\
\hline $\begin{array}{l}\text { mCitrine(GFP-F64L, S65G, V68L, } \\
\text { Q69M, S72A, T203Y, H231L) }\end{array}$ & 5.7 & $\mathrm{~b}$ & $\begin{array}{c}516 \\
77\end{array}$ & 529 & 0.76 & {$[18,19]$} \\
\hline $\begin{array}{l}\text { mtAlpHi (S65G,V68L, Q69K, S72A, } \\
\text { T203Y=Camgaroo2 calmodulin } \\
\text { replaced with short aequorin) }\end{array}$ & 8.5 & b & 498 & 522 & b & {$[20]$} \\
\hline Clover & 6.2 & $\mathrm{~b}$ & $\begin{array}{l}505 \\
111\end{array}$ & 515 & 0.76 & [21] \\
\hline \multicolumn{7}{|c|}{ Red FPs } \\
\hline $\begin{array}{c}\text { mOrange2 (GenBank: DQ336159) } \\
\text { (mOrange-Q64H, F99Y, E160K, G196D) }\end{array}$ & 6.5 & $\mathrm{~b}$ & $\begin{array}{c}549 \\
58\end{array}$ & 565 & 0.60 & {$[22,23]$} \\
\hline $\begin{array}{l}\text { pHTomato (GenBank: JQ966306) } \\
\text { (mStrawberry-F41T, Q66T, F83L, } \\
\text { S182K, I194K, V195T, G196D) }\end{array}$ & 7.8 & $\mathrm{~b}$ & 550 & 580 & $\mathrm{~b}$ & [24] \\
\hline $\begin{array}{c}\text { mNectarine } \\
\text { (GenBank: FJ439505) }\end{array}$ & 6.9 & $\mathrm{~b}$ & $\begin{array}{c}558 \\
58\end{array}$ & 578 & $\mathrm{~b}$ & [25] \\
\hline $\begin{array}{c}\text { mKate } \\
\text { (GenBank: EU383029) }\end{array}$ & 6.2 & $\mathrm{~b}$ & $\begin{array}{c}588 \\
32\end{array}$ & 635 & 0.28 & [26] \\
\hline $\begin{array}{c}\text { mKate2 } \\
\text { (GenBank: JB331973) }\end{array}$ & 5.4 & $\mathrm{~b}$ & $\begin{array}{c}588 \\
63\end{array}$ & 633 & 0.40 & [26] \\
\hline $\begin{array}{c}\text { mTangerine } \\
\text { (GeneBank: AY678270) }\end{array}$ & 5.7 & $\mathrm{~b}$ & $\begin{array}{c}568 \\
38\end{array}$ & 585 & 0.30 & [27] \\
\hline mRuby2 & 5.3 & $\mathrm{~b}$ & $\begin{array}{c}559 \\
43 \\
\end{array}$ & 600 & 0.38 & [21] \\
\hline
\end{tabular}

${ }^{\mathrm{a}}$ Poor or no emission at this wavelength excitation; ${ }^{\mathrm{b}}$ not determined/not applicable. 
An enhanced yellow fluorescent protein (EYFP) has a yellow-shifted absorption and fluorophore emission with respect to conventional green FPs [12,17]. This shift in the spectra is the result of a T203Y substitution. Further, EYFP shows an acidification-dependent decrease in the absorbance peak at $514 \mathrm{~nm}$, an emission peak at $527 \mathrm{~nm}$, and a concomitant increase in the absorbance at $390 \mathrm{~nm}$, which is nonfluorescent. An improved yellow FP mCitrine was generated by Q69M and V68L mutations to EYFP. These substitutions reduce sensitivity to chloride ions, improve maturation at $37{ }^{\circ} \mathrm{C}$, and lower $\mathrm{pK}_{\mathrm{a}}$ to $5.7[18,19]$. The more acidic $\mathrm{pK}_{\mathrm{a}}$ classify mCitrine as a $\mathrm{pH}$ sensor suited for $\mathrm{pH}$ analysis of medial/trans-Golgi, as well as secretory and endocytic organelles [12].

Abad et al. [20] developed a sensor named mtAlpHi for analysis of mitochondrial alkaline $\mathrm{pH}$ with an apparent $\mathrm{pK}_{\mathrm{a}}$ of approximately 8.5. The sensor is composed of EYFP taken from camgaroo-2 [18]. A calmodulin from camgaroo- 2 is replaced with aequorin, comprising 73 amino acids that contain second and third EF-hand domains. mtAlpHi undergoes changes only in fluorescent intensity upon $\mathrm{pH}$ changes; it is prone to potential artifacts of all nonratiometric indicators. However, the co-transfection with mtECFP largely circumvented this drawback.

Some $\mathrm{pH}$-sensitive indicators have an excitation and emission shifted toward red spectra. These red-shifted FPs are particularly practical for multicolor labeling in combination with green or yellow FPs. Thus far, only pHTomato [24] and mNectarine [25] have been used for $\mathrm{pH}$ analysis in living cell imaging. The emission intensities of pHTomato are highly $\mathrm{pH}$-dependent with a $\mathrm{pK}_{\mathrm{a}}$ of 7.8. Along the mtAlpHi [20], this is the highest determined $\mathrm{pK}_{\mathrm{a}}$ among intensity-based $\mathrm{pH}$ sensors, thereby making the sensor suitable for following mitochondrial $\mathrm{pH}$ [24]. The $\mathrm{pH}$ influences the fluorescence intensity of pHTomato, but not the excitation and emission waveforms. Conversely, the absorbance spectra of mNectarine [25] recorded at various $\mathrm{pHs}$ reveal complex changes in profile that appear to include a mixture of anionic cyan-absorbing $(489 \mathrm{~nm})$ and orange-absorbing $(558 \mathrm{~nm})$ forms of the protein at high $\mathrm{pH}$, and a mixture of protonated violet-absorbing $(387 \mathrm{~nm})$ and blue-absorbing $(453 \mathrm{~nm})$ forms of the protein at low $\mathrm{pH}$ [25]. The apparent $\mathrm{pK}_{\mathrm{a}}$ of mNectarine is 6.9, with excitation at $558 \mathrm{~nm}$ and emission measured at $578 \mathrm{~nm}$.

Recently, a new generation of $\mathrm{pH}$-sensitive FPs has been developed with $\mathrm{pK}_{\mathrm{a}}$ values ranging from 5.3 to 6.5; however, they have not been tested as $\mathrm{pH}$ sensors in live cell experiments. The absorption/excitation spectrum for green FP mWasabi is narrower than that of EGFP with the same emission spectra; therefore, less cross-talk is expected when used in combination with blue- and cyan-shifted FPs [16]. The Clover is very bright yellow FP, with an acidic $\mathrm{pK}_{\mathrm{a}}$ of 6.2 , thereby making it suitable for imaging $\mathrm{pH}$ changes of Golgi-network and secretory vesicles [21]. The FPs derived from the Discosoma mRFP are mainly red-shifted [23-26]. Further, Shaner et al. [22] developed two highly photostable mOrange variants by random and iterative mutagenesis. mOrange M163K and mOrange 2 - with $\mathrm{pK}_{\mathrm{a}} 7.5$ and 6.5, respectively — exhibit enhanced photostability, efficient maturation, and increased $\mathrm{pH}$ sensitivity [22,23]. The other $\mathrm{pH}$-sensitive red-shifted FPs are mRuby2, mKate2, mTangerine, and mKate. Their $\mathrm{pK}_{\mathrm{a}}$ varies from 5.3 to 6.2 , which makes them suitable for imaging $\mathrm{pH}$ changes from $<5.0$ to 6.5 [21,26,27]. For example, the maturation of endosomes coincides with a $\mathrm{pH}$ reduction from 6.8 to $<5.5$ [1,28,29]. A drawback for mKate, mRuby2, and mTangerine $\mathrm{pH}$ sensors is that they are not very bright fluorophores with low quantum yield compared to other FPs. The problem can be elegantly solved by tethering two FPs, as done for mOrange [23]. 


\section{Ratiometric Sensors Constituted by a Single Fluorescent Protein}

The emission intensity of intensity-based $\mathrm{pH}$ indicators depends on the total concentration of fluorophore; therefore, it is difficult to determine whether observed changes in fluorescence are due to $\mathrm{pH}$ change or indicator concentration. An elegant way to circumvent the problem of the intensity-based $\mathrm{pH}$ indicators are ratiometric $\mathrm{pH}$ indicators that do not require an independent means of measuring the concentration of protein. Dual excitation ratiometric $\mathrm{pH}$ sensors have bimodal excitation spectra, and some also have dual-emission spectra with dose-dependent changes in excitation/emission at increasing acidity (Table 2). These features are an important advantage over the attributes of a single-wavelength FPs, such as e-pHluorin, because they make ratiometric sensors resistant to photo-bleaching and provide variability of indicator loading.

Table 2. Ratiometric pH-sensitive fluorescent proteins.

\begin{tabular}{|c|c|c|c|c|c|c|}
\hline & \multirow{2}{*}{ pK } & $\lambda_{\mathrm{x} 1}(\mathrm{~nm})$ & $\lambda_{\mathrm{x} 2}(\mathrm{~nm})$ & \multirow{2}{*}{$\lambda_{\mathrm{e} 1}(\mathrm{~nm})$} & \multirow{2}{*}{$\lambda_{\mathrm{e} 2}(\mathrm{~nm})$} & \multirow{2}{*}{ Reference } \\
\hline & & \multicolumn{2}{|c|}{$\varepsilon\left(\mathrm{mM}^{-1} \cdot \mathrm{cm}^{-1}\right)$} & & & \\
\hline \multicolumn{7}{|c|}{ pHluorins } \\
\hline $\begin{array}{c}\text { R-pHluorin (GenBank: AF058694) } \\
\text { (GFP-E132D, S147E, N149L, N164I, } \\
\text { K166Q, I167V, R168H, L220F) }\end{array}$ & 6.9 & 395 & 475 & $508^{a}$ & $\mathrm{~b}$ & {$[13]$} \\
\hline $\begin{array}{l}\text { R-pHluorin2 } \\
\text { (R-pHluorin-F64L, Q80R, E132D, S175G) }\end{array}$ & 7.1 & 395 & 475 & $509^{\mathrm{a}}$ & $\mathrm{b}$ & {$[30,31]$} \\
\hline $\begin{array}{l}\text { R-pHluorin(M153R) } \\
\text { (R-pHluorin-M153R) }\end{array}$ & 7.1 & 395 & 475 & $509^{\mathrm{a}}$ & $\mathrm{b}$ & {$[32]$} \\
\hline pHGFP & $\mathrm{b}$ & 410 & 470 & $535^{\mathrm{a}}$ & $\mathrm{b}$ & {$[15]$} \\
\hline PrpHluorin (R-pHluorin for plants) & 6.6 & 395 & 475 & $515^{\mathrm{a}}$ & $\mathrm{b}$ & [4] \\
\hline RaVC (R-pHluorin-XX) & 7.1 & 395 & 476 & $508^{\mathrm{a}}$ & $\mathrm{b}$ & {$[33,34]$} \\
\hline \multicolumn{7}{|c|}{ deGFP } \\
\hline deGFP1 (S65T,Q80R, H148G, T203C) & 8.0 & 400 & 504 & 466 & 516 & {$[35]$} \\
\hline deGFP2 (S65T, C48S, Q80R, H148C) & 7.3 & 398 & 496 & 462 & 517 & {$[35]$} \\
\hline deGFP3 (S65T, Q80R, T203C) & 6.9 & 396 & 508 & 461 & 518 & {$[35]$} \\
\hline $\begin{array}{c}\text { deGFP4 } \\
\text { (S65T, C48S, Q80R, H148C, T203C) }\end{array}$ & 7.4 & 400 & 509 & 462 & 518 & {$[35]$} \\
\hline \multicolumn{7}{|c|}{$E^{n}$ GFP } \\
\hline $\begin{array}{c}\text { E }^{2} \text { GFP } \\
(\text { GFP-F64L, S65T, T203Y, L231H) }\end{array}$ & $6.9-7.5^{\mathrm{e}}$ & $\begin{array}{c}423 / 401^{\mathrm{d}} \\
32 / 23\end{array}$ & $\begin{array}{c}515 \\
22\end{array}$ & $510 / 523^{d}$ & $\mathrm{~b}$ & {$[36]$} \\
\hline $\begin{array}{c}\mathrm{E}^{1} \mathrm{GFP} \\
(\mathrm{GFP}-\mathrm{F} 64 \mathrm{~L}, \mathrm{~T} 203 \mathrm{Y})\end{array}$ & $6.4-6.6^{\mathrm{e}}$ & $\begin{array}{c}410 / 400^{\mathrm{d}} \\
31 / 29\end{array}$ & $\begin{array}{c}509 \\
5 \\
\end{array}$ & $510 / 523^{d}$ & $\mathrm{~b}$ & [37] \\
\hline \multicolumn{7}{|c|}{ Others } \\
\hline Wt-CoGFP & $6.5^{\mathrm{e}}$ & 388 & 498 & $456 / 507^{\mathrm{d}}$ & 507 & {$[38]$} \\
\hline$P t-\mathrm{GFP}$ & 7.3 & 390 & 502 & $508^{\mathrm{a}}$ & $\mathrm{b}$ & {$[39]$} \\
\hline pHRed (mKeima-A213S) & $7.8 ; 6.9^{\mathrm{c}}$ & 440 & 585 & $610^{\mathrm{a}}$ & $\mathrm{b}$ & {$[40]$} \\
\hline SypHer (HyPer-C199S) & 8.7 & 420 & 490 & $535^{\mathrm{a}}$ & $\mathrm{b}$ & [41] \\
\hline
\end{tabular}

${ }^{a}$ Valid for both excitations $(\lambda \times 1$ and $\lambda \times 2) ;{ }^{b}$ not determined/not applicable; ${ }^{c}$ pK determined with FLIM; ${ }^{\mathrm{d}}$ at $\mathrm{pH}<5 / \mathrm{at} \mathrm{pH}>8,{ }^{\mathrm{e}} \mathrm{pK}$ depends on combination of excitation/emission set up. 
The first study on ratiometric GFP by excitation was that of Miesenbock et al. [13]. Ratiometric GFP also called ratio-pHluorin (r-pHluorin), and displays an increase in fluorescence at $508 \mathrm{~nm}$ after a 475-nm excitation concomitantly with a decrease after a 395-nm excitation upon a $\mathrm{pH}$ shift from 7.5 to 5.5, with apparent $\mathrm{pK}_{\mathrm{a}}$ of 6.9. The functionality of $\mathrm{r}$-pHluorin has been initially tested expressed in trans-Golgi network, endosomes, and synapses. Subsequently, a modification to r-pHluorin was introduced to enhance the brightness of pHluorin, which was achieved with additional mutations F64L and S65T [30], which are characteristic for EGFP [11]. pHluorin2 is used for $\mathrm{pH}$ analysis in human cell lines and yeast Saccharomyces cerevisiae [30,31]. Further, a M153R mutation in the r-pHluorin increases the brightness of e-pHluorinM153R and its in vivo stability, while it does not affect the $410 / 470 \mathrm{~nm}$ excitation ratios at various $\mathrm{pH}$ values [32]. The r-pHluorin with mutation A206K named $\mathrm{RaVC}$ has been used to study the $\mathrm{pH}_{\mathrm{i}}$ of the filamentous fungus Aspergillus niger [33,34]. A plant dual-excitation ratiometric pHluorin, PRpHluorin — which is similar to PEpHluorin [4] - is a fusion between a soluble modified GFP (smGFP) [15] with F99S mutation and pHluorin with additional mutations M153T and V163A [4]. The presence of smGFP decreases $\mathrm{pK}_{\mathrm{a}}$ to 6.6 with no effect on the spectral waveforms of pHluorin.

Hanson et al. [35] introduced four ratiometric sensors named deGFP1 (S65T, H148G, and T203C), deGFP2 (S65T, C48S, and H148C), deGFP3 (S65T and T203C), and deGFP4 (S65T, C48S, H148C, and $\mathrm{T} 203 \mathrm{C}$ ) that are ratiometric by emission. The deGFPs have a $\mathrm{pK}_{\mathrm{a}}$ ranging from 6.8 to 8.0. With acidification, with the excitation of deGFPs at $400 \mathrm{~nm}$, a green emission (peak at $515 \mathrm{~nm}$ ) converts to a blue one with a peak at $460 \mathrm{~nm}$. In addition, the anionic chromophore is directly excited at 480-500 nm, and only a green emission is detected. Therefore, the pH-dependent dual emission is defined at 460 and $515 \mathrm{~nm}$ for excitation of a neutral chromophore at $400 \mathrm{~nm}$. The deGFPs are very promising for bioimaging applications, particularly for two-photon excitation.

E $^{2}$ GFP, a GFP (F64L, S65T, T203Y) variant [36], belongs to the yellow FP class and displays ratiometric characteristics similar to deGFPs [35]. The $E^{2}$ GFP is an excellent ratiometric sensor by excitation (e.g., $\lambda_{\mathrm{x}} 458$ and $\left.488 \mathrm{~nm} ; \lambda_{\mathrm{e}} 500-600 ; \mathrm{pK}_{\mathrm{a}} 6.9\right)$ and by emission $\left(\lambda_{\mathrm{x}} 458 \mathrm{~nm} ; \lambda_{\mathrm{e}} 475-525\right.$ and $\left.515-600 \mathrm{~nm} ; \mathrm{pK}_{\mathrm{a}} 7.5\right)$. The sensor is quenched by halide ions, but the ratiometric measurements are not affected due to its ratiometric characteristics. Subsequently, $E^{1}$ GFP [37] was developed; it is spectroscopically similar to $\mathrm{E}^{2} \mathrm{GFP}$, but less sensitive to halide ions and with a $\mathrm{pK}_{\mathrm{a}}$ ranging from 6.4-6.6; therefore, it is more tailored for mildly acidic intracellular compartments. The fluorescence spectra are consistent with the presence of two $\mathrm{pH}$-interconverting forms. Excitation at 408 and $473 \mathrm{~nm}$ yields a pH-dependent emission spectra with a peak at $508-510 \mathrm{~nm}$, which is red-shifted (peak at $523 \mathrm{~nm}$ ) as the $\mathrm{pH}$ increases. Further, for live cell imaging, two excitation-wavelength ratiometric setups were used: excitations $488 \mathrm{~nm}$ and $458 \mathrm{~nm}$ or $488 \mathrm{~nm}$ and $406 \mathrm{~nm}$ with an emission interval of 500 to $600 \mathrm{~nm}$.

The sea cactus Cavernularia obesa GFP (CoGFP)- like deGFP and $\mathrm{E}^{\mathrm{n}} \mathrm{GFP}$ - has pH-sensitive, ratiometric dual-excitation/emission properties, and dual-color emission maxima upon single-wavelength excitation [38]. The excitation at $388 \mathrm{~nm}$ leads to blue fluorescence with a peak at $456 \mathrm{~nm}$ at pH 5 and below, and green fluorescence with a peak at $507 \mathrm{~nm}$ at $\mathrm{pH} 7$ and above. Excitation at $498 \mathrm{~nm}$ triggers green fluorescence with a peak at $507 \mathrm{~nm}$ from $\mathrm{pH}$ 5-9. Further, fluorescence at $507 \mathrm{~nm}$ is ratiometric to that at 456 and $388 \mathrm{~nm}$ excitation, with $\mathrm{pK}_{\mathrm{a}} 6.5$. Additional 
mutations to wtCoGFP generated either brighter fluorescence or different spectral characteristics. It must be noted that only variant- 0 has been tested further in live cell imaging.

Shulte et al. [39] developed a novel GFP variant isolated from the orange seapen Ptilosarcus gurneyi with good $\mathrm{pH}$ responsiveness and excellent dynamic ratio range. The Pt-GFP is ratiometric by excitation; however, the $\mathrm{pH}$ dependency of the fluorescence spectra is just opposite to that of pHluorin. The Pt-GFP with $\mathrm{pK}_{\mathrm{a}} 7.3$ displays an increase in 540-nm fluorescence after a 390-nm excitation concomitantly with a decrease after a 510-nm excitation upon a $\mathrm{pH}$ shift from 7.5 to 5.5. The $P t$-GFP sensor is also stable at a $\mathrm{pH}$ below 5 , which is an advantageous feature when organelles with low $\mathrm{pH}$ are labeled.

Thus far, only one red-shifted ratiometric $\mathrm{pH}$ sensor has been identified. Tantama et al. [40] engineered a ratiometric $\mathrm{pH}$ sensor, $\mathrm{pHRed}$ by mutagenesis of the long Stokes-shifted fluorescent protein mKeima. The peak fluorescence emission of pHRed occurs at $610 \mathrm{~nm}$. The acidification from pH 9 to 6 causes a 7-fold increase in the $585 \mathrm{~nm}$ peak intensity and a 4-fold decrease in the $440 \mathrm{~nm}$ peak intensity; both peaks respond with a $\mathrm{pK}_{\mathrm{a}}$ of 7.8. Moreover, $\mathrm{pHRed}$ exhibits a $\mathrm{pH}$-dependent fluorescence lifetime that makes the pHRed suitable for imaging intracellular $\mathrm{pH}$ by fluorescence lifetime imaging microscopy (FLIM).

SypHer [41], a ratiometric circularly permutated YFP HyPer [42] with C199S mutation, is the only ratiometric $\mathrm{pH}$ sensor with a $\mathrm{pK}_{\mathrm{a}}$ of above 8 . The $\mathrm{pK}_{\mathrm{a}}$ of 8.7 permits accurate measurements of mitochondrial $\mathrm{pH}$. The fluorescence intensity at $535 \mathrm{~nm}$ increases markedly with $\mathrm{pH}$ at an excitation wavelength of around $490 \mathrm{~nm}$ and mildly decreases at an excitation wavelength of $405 \mathrm{~nm}$.

\section{Other genetically Encoded pH Sensitive Sensors}

By joining two or more FPs with different $\mathrm{pH}$-dependency of fluorescence spectra, a new chimeric FP with novel excitation/emission spectra and altered $\mathrm{pH}$-dependency is synthesized (Table 3). This approach is mainly used to convert intensity-based FPs to ratiometric $\mathrm{pH}$ sensors. Using a synthetic biology approach, we can generate numerous combinations of FPs and tailor the FPs to our requirements.

Three novel ratiometric $\mathrm{pH}$ sensitive sensors GFpH, YFpH [43], and pHERP [44] were obtained by fusing GFPuv, a low-pH sensitivity mutant excitable at $380 \mathrm{~nm}$, with an intensity-based $\mathrm{pH}$ sensitive GFP, EGFP, or EYFP. The YFpH and pHERP sensor are both fusions of GFPuv and EYFP, with changed order of named FPs. When excited at $380 \mathrm{~nm}$ and $480 \mathrm{~nm}$, the GFpH emits at $510 \mathrm{~nm}$. The $\mathrm{pK}_{\mathrm{a}}$ of GFpH is 5.6 (380 nm excitation) and 6.2 (480 nm excitation) and the apparent $\mathrm{pK}_{\mathrm{a}}$ is 6.2 . The fluorescence maximum of $\mathrm{YFpH}$ and pHERP is $527 \mathrm{~nm}$ when excited at $480 \mathrm{~nm}$ and the apparent $\mathrm{pK}_{\mathrm{a}}$ is 6.5. Upon excitation at $380 \mathrm{~nm}$, the emission of YFpH and pHERP shifts from $527 \mathrm{~nm}$ to $506 \mathrm{~nm}$ with the acidification.

Arosio et al. [45] developed the ratiometric sensor ClopHensor that is suited for real-time optical detection of chloride ions and $\mathrm{pH}$ in live cells. The ClopHensor exploits the spectral and chemical characteristics of the $E^{2}$ GFP anion-binding site [36] that is linked to the DsRed, a fluorescent protein, which is insensitive for protons and chloride ions. With tethering $\mathrm{E}^{2} \mathrm{GFP}$ to DsRed, the $\mathrm{pH}$-sensitive spectral characteristics of $E^{2}$ GFP remain unchanged. Mutations H148 and V224L of ClopHensor shift $\mathrm{pK}_{\mathrm{a}}$ to more alkaline values and improve affinity for chloride ions [46]. 
pHusion [47] is composed of a tandem concatenation of EGFP and mRFP1, and also function as a ratiometric $\mathrm{pH}$ sensor. To obtain a 1:1 stoichiometry, the two fluorescent proteins are fused by a short peptide linker, permitting for ratiometric measurements of $\mathrm{pH}$ changes, where mRFP1 functions as an intramolecular reference.

Table 3. pH-sensitive fluorescent proteins.

\begin{tabular}{|c|c|c|c|c|c|c|}
\hline & pK & $\lambda_{\mathrm{x} 1}(\mathrm{~nm})$ & $\lambda_{\mathrm{x} 2}(\mathrm{~nm})$ & $\lambda_{\mathrm{e} 1}(\mathrm{~nm})$ & $\lambda_{\mathrm{e} 2}(\mathrm{~nm})$ & Reference \\
\hline GFpH GFPuv-EGFP & 6.1 & 380 & 480 & 510 & a & [43] \\
\hline YfpH GFPuv-EYFP & 6.5 & 380 & 480 & $509 / 527$ & $\mathrm{a}$ & [43] \\
\hline $\begin{array}{c}\text { pHERP } \\
\text { EYFP-GGGLEDPRVPVEK-GFPuv }\end{array}$ & 6.5 & 397 & 515 & 520 & $\mathrm{a}$ & [44] \\
\hline $\begin{array}{c}\text { ClopHensor } \\
\text { E }^{2} \text { GFP-linker } 20 \text { aa-dsRedm }\end{array}$ & 6.8 & 458 and 488 & $\begin{array}{l}543 \text { for } \\
\text { DsRed }\end{array}$ & 590 & $\begin{array}{l}630 \text { for } \\
\text { DsRed }\end{array}$ & [45] \\
\hline $\begin{array}{c}\text { ClopHensor } \\
(\mathrm{H} 148 \mathrm{G}, \mathrm{V} 224 \mathrm{~L})\end{array}$ & 7.3 & 458 and 488 & $\begin{array}{l}543 \text { for } \\
\text { DsRed }\end{array}$ & 535 & $\begin{array}{l}630 \text { for } \\
\text { DsRed }\end{array}$ & [46] \\
\hline $\begin{array}{c}\text { pHusion } \\
\text { mRFP1- }{ }^{\text {AVNAS }} \text {-EGFP }\end{array}$ & 5.8 & 488 & 558 or 585 & $500-550$ & $600-630$ & [47] \\
\hline
\end{tabular}

${ }^{\mathrm{a}}$ not determined/not applicable.

The concatenation of $\mathrm{pH}$-sensitive with $\mathrm{pH}$-insensitive FPs can be used for the combination of virtually any FPs, assuming that the excitation and emission spectra of concatenated FPs do not overlap. Such fusions are sensitive for photo-bleaching; moreover, more sophisticated equipment is required due to multi-excitation/emission spectral properties.

\section{5. pH in Cellular Organelles}

The compartmentalization of the eukaryotic cell provides distinct environmental conditions for the optimal operation of individual metabolic pathways. The function of individual organelles depends on the stringently regulated $\mathrm{pH}$ (Figure 2) because protons dictate the charge of macromolecules and generate transmembrane electric potential $[1,3]$. To study $\mathrm{pH}_{\mathrm{i}}$ in vivo, accurate $\mathrm{pH}$ determination is essential. In this section, we outline the genetically encoded sensors applied to monitor the $\mathrm{pH}$ of individual subcellular compartments (Table 4).

Most organelles, except nucleus, have their own specific $\mathrm{pH}$ value associated with the processes that occur in these compartments. The nuclear membrane has an abundance of pores that are a weak barrier for protons; therefore, nuclear $\mathrm{pH}\left(\mathrm{pH}_{\mathrm{N}}\right)$ is similar to that of the surrounding cytosol. Both cytosolic $\mathrm{pH}\left(\mathrm{pH}_{\mathrm{C}}\right)$ and $\mathrm{pH}_{\mathrm{N}}$ of various resting cells are slightly above neutral, between 7.2 and 7.7 (Figure 1, and see Tables 4-7 for references) [11,12,33,34,36,39,40,44,46,48]. To specifically relocate the $\mathrm{pH}$ sensor to the nucleus, a nuclear localization signal NLS is fused to pHluorin [4,49]. A cytosolic sublocation of pHluorin tethered with palmitoylation site, caveolin-1, $\alpha 1 \mathrm{~B}$-adrenoreceptor, or hCTN3 revealed that the $\mathrm{pH}$ of these cytosolic microdomains is not uniform and is 7.3, 7.3, 6.8, or 6.5-7.5, respectively $[25,43,46,50,51]$. The $\mathrm{pH}_{\mathrm{C}}$ of yeasts $S$. cerevisiae, Candida glabrata, and Schizosaccharomyces pombe is highly influenced by environmental changes, such as nutrients and external $\mathrm{pH}$. Their $\mathrm{pH}_{\mathrm{C}}$ differs from 6.4 when cells are starved to 7.5 when glucose is present in the media $[31,49,52-55]$. The $\mathrm{pH}_{\mathrm{C}}$ is also not uniform throughout plant tissues. The $\mathrm{pH}_{\mathrm{C}}$ of $A$. thaliana 
varies from 6.4 at the root cap to 7.3 in meristem cells, thereby proving the presence of significant $\mathrm{pH}$ gradients among different developmental regions in plant roots $[4,15,47]$.

Figure 2. The $\mathrm{pH}$ of individual subcellular compartments in a prototypic eukaryotic cell. We show only $\mathrm{pH}$ values obtained using the genetically encoded $\mathrm{pH}$-sensitive FPs as indicators. The $\mathrm{pH}$ values are collected from different sources and are referenced in Table 4.

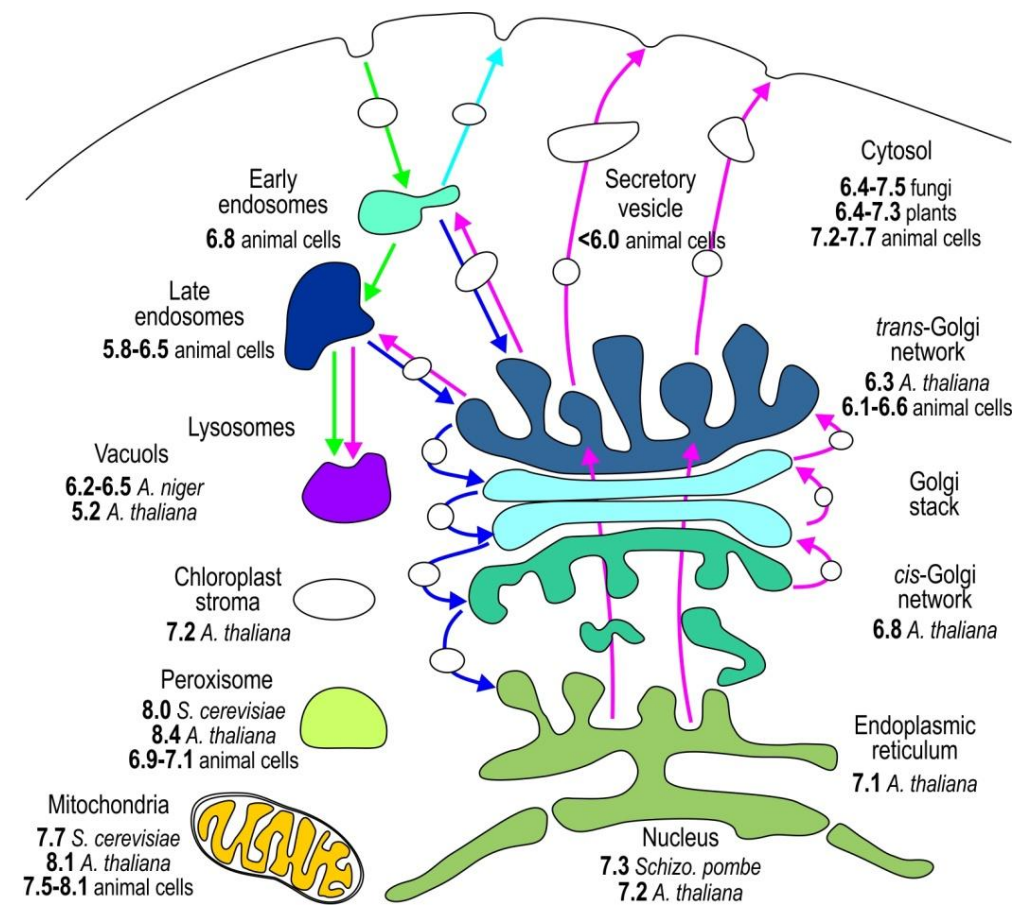

The $\mathrm{pH}$ sensors targeted to the lumen of endoplasmic reticulum via retrograde transport based on KDEL receptor show that the $\mathrm{pH}$ of endoplasmic reticulum $\left(\mathrm{pH}_{\mathrm{ER}}\right)$ is very close to its $\mathrm{pH}_{\mathrm{C}}[4,11,56]$. The luminal $\mathrm{pH}$ throughout the secretory pathway becomes progressively more acidic (Figure 2, Table 5). The cis-Golgi with pH 6.8 is more acidic than the endoplasmic reticulum [4], and the acidification becomes more apparent when the $\mathrm{pH}$ changes from 6.1 to 6.6 in the trans-Golgi network. Rivinoja et al. [57] used GT-EGFP to show that the medial/trans-Golgi pH in cancer cells MCF-7 and HT-29, SW-48, is significantly more alkaline $\left(\mathrm{pH}\right.$ 6.75) than in control cells $\left(\mathrm{pH}_{\mathrm{G}}\right.$ 5.9-6.5), thereby clearly emphasizing the importance of stringent $\mathrm{pH}$ homeostasis. Tagging subcellular domains of Golgi is rather difficult. Many Golgi proteins reside in endoplasmic reticulum for a short period of time, thereby indicating that proteins normally cycle between the Golgi and endoplasmic reticulum [58]. Furthermore, some Golgi proteins such as TGN38/46, a trans-Golgi network (TGN) protein [59], and GPP130, a cis-Golgi protein [60], cycle between the Golgi and endosomes. Directing the $\mathrm{pH}$ sensor to medial/trans-Golgi is achieved with N-terminal linking pHluorin to $\beta-1$, 4-galactosyltransferase [11,12,57,61], 2,6-sialyltransferase [44], and TGN38 in a trans-Golgi network [59]. ManI-PpHluorin-pHluorin fused with glycine max mannosyl-oligosaccharide 1,2-alpha-mannosidase - is used to specify the cis-Golgi luminal $\mathrm{pH}$ [4]. 
Table 4. Select examples of pH-sensitive FPs targeted to cytosol, nucleus, and endoplasmic reticulum.

\begin{tabular}{|c|c|c|c|c|c|}
\hline Sensor & Tag & pH & Organism/Cell Type & Instrument $^{\mathrm{a}}$ & Reference \\
\hline \multicolumn{6}{|c|}{ Cytosol } \\
\hline $\mathrm{E}^{2} \mathrm{GFP}$ & & $7.2-7.3$ & CHO, U-2 OS cells & Micro & [36] \\
\hline $\mathrm{E}^{2} \mathrm{GFP}$ & & $7.3-7.5$ & Rat hippocampal neuron & Micro & [48] \\
\hline deGFP4 & & $7.4-7.7$ & Rat hippocampal neuron & Micro & [48] \\
\hline GFP-F64L/S65T & & 7.4 & CHO- $1 \mathrm{~K}$ cells & Micro & [11] \\
\hline EYFP & & 7.4 & HeLa cells & Micro & [12] \\
\hline SypHer & & 7.2 & HeLa cells & Micro & [41] \\
\hline pHRed & & 7.4 & Neuro 2A cells & Micro & [40] \\
\hline pHERP & & $7.2-7.5$ & Vero, CFT1, CHO cells & Micro & {$[44]$} \\
\hline ClopHensor & & $7.3,7.7$ & WSS1, PC12, CHO cells & Micro & {$[45,46]$} \\
\hline $\begin{array}{c}\text { ClopHensor } \\
\text { (H148G/V224L) }\end{array}$ & & $7.5-7.7$ & $\mathrm{CHO}$ cells & Micro & [46] \\
\hline PalmPalm-ClopHensor & Palmitoylation site & 7.3 & WSS1, PC12 cells & Micro & [46] \\
\hline GFpH & $\begin{array}{c}\text { C-terminus } \\
\alpha 1 \mathrm{~B}-\text { adrenoreceptor }\end{array}$ & 6.8 & COS-7, CHO-K1 cells & Micro & {$[43]$} \\
\hline Caveolin-E ${ }^{1}$ GFP & Caveolin-1 & 7.3 & HeLa cells & Micro & [50] \\
\hline hCNT3-mNectarine & $\begin{array}{c}\text { Cytosolic site of } \\
\text { hCNT3 }\end{array}$ & $6.5-7.5$ & HEK cells & Micro & {$[25]$} \\
\hline $\mathrm{RaVC}$ & & $7.4-7.7$ & A. niger & Micro & {$[33,34]$} \\
\hline pHluorin & & $6.4-7.5^{\mathrm{c}}$ & $\begin{array}{l}\text { S. cerevisiae FL100, S288c, } \\
\sum 1278, \text { ORY001, BY } 4742\end{array}$ & Spec & [52-54] \\
\hline pHluorin, pHluorin2 & & $7.0-7.5^{\mathrm{c}}$ & $\begin{array}{c}\text { S. cerevisiae } \mathrm{H} 4307, \mathrm{H} 3909 \text {, } \\
\text { BY4743 }\end{array}$ & $\begin{array}{l}\text { Micro } \\
\text { Flow }\end{array}$ & {$[31,55]$} \\
\hline pHluorin & & $7.2-7.3$ & Schizo. pombe & Micro & [49] \\
\hline pHluorin & & $7.0^{\mathrm{c}}$ & C. glabrata BG14 & Spec & [51] \\
\hline pHusion & & 6.4 & Arabidopsis mesophyll cell & Micro & [47] \\
\hline pHGFP & & $6.5-7.0$ & A. thaliana root cap & Micro & [15] \\
\hline pHGFP & & $7.0-7.3$ & A. thaliana meristem cells & Micro & [15] \\
\hline PRpHluorin & & 7.3 & A. thaliana & Micro & [4] \\
\hline \multicolumn{6}{|c|}{ Nucleus } \\
\hline NLS-PRpHluorin & PKKKRKV & 7.2 & A. thaliana & Micro & {$[4]$} \\
\hline pHluorin-NLS & PKKKRKV & 7.3 & Schizo. pombe & Micro & [49] \\
\hline \multicolumn{6}{|c|}{ Endoplasmic reticulum } \\
\hline pHluorin-KDEL & $\begin{array}{c}\text { KDEL at C-terminus } \\
\text { of FP }\end{array}$ & $\mathrm{b}$ & Rat hippocampal neurons & Micro & [56] \\
\hline $\begin{array}{l}\text { GFP-F64L/S65T- } \\
\text { SEKDEL }\end{array}$ & $\begin{array}{l}\text { SEKDEL at C- } \\
\text { terminus of FP }\end{array}$ & $\mathrm{b}$ & CHO-K1, LLC-PK1 cells & Micro & [11] \\
\hline PpHluorin-HDEL & $\begin{array}{l}\text { HDEL at C-terminus } \\
\text { of FP }\end{array}$ & 7.1 & A. thaliana & Micro & [4] \\
\hline
\end{tabular}

${ }^{a}$ Micro, FLIM, spec, flow stand for microscopy, fluorescence life time microscopy, spectrophotometry and flow cytometry, respectively; ${ }^{\mathrm{b}}$ Only $\mathrm{pH}$ changes are presented in the paper; ${ }^{\mathrm{c}}$ Dependent on carbon source, external $\mathrm{pH}$. 
Table 5. Select examples of pH-sensitive FPs targeted to Golgi.

\begin{tabular}{|c|c|c|c|c|c|c|}
\hline & Sensor & Tag & pH & Organism/Cell Type & Instrument $^{\mathrm{a}}$ & Reference \\
\hline $\begin{array}{l}\text { Medial/ } \\
\text { trans }\end{array}$ & $\begin{array}{l}\text { GT-EGFP, } \\
\text { GT-ECFP, } \\
\text { GT-EYFP }\end{array}$ & $\begin{array}{c}\beta-1, \\
\text { 4-galactosyltransferase } \\
(\text { N-terminal 81aa) }\end{array}$ & 6.6 & $\begin{array}{l}\text { HeLa CHO-K1, } \\
\text { LLC-PK1 cells }\end{array}$ & Micro & {$[11,12]$} \\
\hline $\begin{array}{l}\text { Mediall } \\
\text { trans }\end{array}$ & $\begin{array}{l}\text { GT-EGFP/ } \\
\text { GT-ECFP }\end{array}$ & $\begin{array}{c}\beta-1, \\
\text { 4-galactosyltransferase }\end{array}$ & 6.4 & HeLa cells & Micro & [61] \\
\hline $\begin{array}{l}\text { Mediall } \\
\text { trans }\end{array}$ & $\begin{array}{l}\text { GT-EYFP/ } \\
\text { GT-ECFP }\end{array}$ & $\begin{array}{c}\beta-1, \\
\text { 4-galactosyltransferase }\end{array}$ & 6.4 & HeLa cells & Micro & [61] \\
\hline $\begin{array}{l}\text { Medial/ } \\
\text { trans }\end{array}$ & GT-EGFP & $\begin{array}{c}\beta-1, \\
\text { 4-galactosyltransferase }\end{array}$ & 6.8 & $\begin{array}{l}\text { Cancer cells MCF-7, } \\
\text { HT-29, SW-48 cells }\end{array}$ & Micro & [57] \\
\hline $\begin{array}{l}\text { Medial/ } \\
\text { trans }\end{array}$ & GT-EGFP & $\begin{array}{c}\beta-1, \\
\text { 4-galactosyltransferase }\end{array}$ & $6.1-6.3$ & $\begin{array}{c}\text { COS7, } \mathrm{CaCo} 2 \text { cells, } \\
\text { fibroblasts }\end{array}$ & Micro & [57] \\
\hline $\begin{array}{l}\text { Medial/ } \\
\text { trans }\end{array}$ & ST-pHERP & $\begin{array}{c}\text { 2,6-sialyltransferase } \\
\text { (1-70 aa) }\end{array}$ & $6.4-6.6$ & $\begin{array}{c}\text { CFT1, Vero, CHO, } \\
\text { HeLa cells }\end{array}$ & Micro & [44] \\
\hline TGN & $\begin{array}{l}\text { TGN38- } \\
\text { pHluorin }\end{array}$ & $\begin{array}{c}\text { Trans Golgi network } \\
\text { protein }\end{array}$ & 6.4 & HEK cells & Micro & [59] \\
\hline TGN & $\begin{array}{l}\text { PpHluorin- } \\
\text { BP80 } \\
\text { (Y612A) }\end{array}$ & $\begin{array}{l}\text { BP-80 vacuolar sorting } \\
\text { receptor }\end{array}$ & 6.3 & A. thaliana & Micro & [4] \\
\hline Cis & $\begin{array}{c}\text { ManI- } \\
\text { PpHluorin }\end{array}$ & mannosidase & 6.8 & A. thaliana & Micro & [4] \\
\hline
\end{tabular}

${ }^{a}$ Micro, FLIM, spec, flow stand for microscopy, fluorescence life time microscopy, spectrophotometry and flow cytometry.

Due to the heterogeneity of secretory vesicles and their acidification during secretion, the analysis of vesicular $\mathrm{pH}$ presents a serious challenge (Table 6). Primarily, e-pHluorin is used for the analysis of vesicular dynamics; therefore, spatial and temporal $\mathrm{pH}$ changes rather than the $\mathrm{pH}$ of recycling vesicles are known. Synaptic vesicles maintain an acidic lumen with a resting $\mathrm{pH}$ value of 5.6 [13]. Therefore, instead of pHluorins, FPs with a $\mathrm{pK}_{\mathrm{a}}$ of almost 6 might be better suited for $\mathrm{pH}$ measurements of acidic subcellular compartments, including maturing endosomes. During the so-called process of de-granulation, lytic granules and synaptic vesicles release their content when fusing to the plasma membrane [62]. The dynamics of secretory vesicles have been studied using DsRed-FasL-e - pHluorin for visualizing fusion pore openings [62], VGLUT1-2xmOrange2, VGLUT1-pH, and synapto-pHluorin and SytIV-pHluorin for monitoring re-acidification of synaptic vesicles after endocytosis [11,13,14,23,24,63-66]. Since synaptophysin displays less background expression on the plasma membrane than synaptobrevin/VAMP2, synaptophysin is used for an improved sypHTomato reporter of vesicular turnover [24]. Dean et al. [67] used e-pHluorin to report the location and $\mathrm{pH}$ of organelles to which the synaptotagmin isoforms are targeted. Among 15 isoforms, only syt-1 and 2 are targeted to synaptic vesicles; the other 13 are located in dendrites and axons.

Spatial and temporal $\mathrm{pH}$ changes have been analyzed for many specialized vesicles, such as insulin secretory granules [68], large dense-core vesicles [45] and maturing endosomes [4,50,59]. pHluorin, ECFP, and $\mathrm{E}^{1} \mathrm{GFP}$ are targeted to vesicles through fusing the $\mathrm{pH}$ sensor to luminal site of proteins that are characteristic of those vesicles $[4,30,50,56,59,68,69]$. 
Table 6. Select examples of pH-sensitive FPs targeted to subcellular compartments of secretory and endocytic pathway.

\begin{tabular}{|c|c|c|c|c|c|c|}
\hline & Sensor & Tag & pH & Organism/Cell Type & Instrument $^{\mathrm{a}}$ & Reference \\
\hline $\begin{array}{l}\text { Perforin } \\
\text { containing } \\
\text { granules }\end{array}$ & $\begin{array}{l}\text { DsRed-FasL- } \\
\text { pHluorin }\end{array}$ & Fas ligand & $\mathrm{b}$ & NKL cells & Micro & {$[62]$} \\
\hline $\begin{array}{c}\text { BDNF } \\
\text { containing } \\
\text { vesicles and } \\
\text { Golgi }\end{array}$ & SytIV-pHluorin & Synaptotagmin-IV & $\mathrm{b}$ & Rat hippocampal neurons & Micro & {$[63]$} \\
\hline $\begin{array}{l}\text { Synaptic } \\
\text { vesicles }\end{array}$ & pHluorin-syt & $\begin{array}{c}\text { Luminal domain of } \\
\text { synaptotagmins }\end{array}$ & $\mathrm{b}$ & Rat hippocampal neurons & Micro & {$[67]$} \\
\hline $\begin{array}{l}\text { Synaptic } \\
\text { vesicles }\end{array}$ & syp-pHTomato & Synaptophysin & $\mathrm{b}$ & $\begin{array}{c}\text { HEK, rat hippocampal } \\
\text { neurons }\end{array}$ & Micro & {$[24]$} \\
\hline $\begin{array}{l}\text { Synaptic } \\
\text { vesicles }\end{array}$ & VAMP2-pHTomato & $\begin{array}{c}\text { Synaptobrevin/ } \\
\text { VAMP2 }\end{array}$ & $\mathrm{b}$ & $\begin{array}{c}\text { HEK, rat hippocampal } \\
\text { neurons }\end{array}$ & Micro & {$[24]$} \\
\hline $\begin{array}{l}\text { Synaptic } \\
\text { vesicles }\end{array}$ & GFP-F64L/S65T- & $\begin{array}{c}\text { Synaptobrevin/ } \\
\text { VAMP2 }\end{array}$ & $\mathrm{b}$ & CHO-K1, LLC-PK1 cells & Micro & [11] \\
\hline $\begin{array}{l}\text { Synaptic } \\
\text { vesicles }\end{array}$ & VAMP-EGFP & $\begin{array}{c}\text { Synaptobrevin/ } \\
\text { VAMP2 }\end{array}$ & $\mathrm{b}$ & Rat hippocampal neurons & Micro & [14] \\
\hline $\begin{array}{l}\text { Synaptic } \\
\text { vesicles }\end{array}$ & synapto-e $\mathrm{s}_{\mathrm{s}}-\mathrm{pHluorin}$ & $\begin{array}{c}\text { Synaptobrevin/ } \\
\text { VAMP2 }\end{array}$ & $\mathrm{b}$ & Rat hippocampal neurons & Micro & [14] \\
\hline $\begin{array}{l}\text { Synaptic } \\
\text { vesicles }\end{array}$ & $\begin{array}{c}\text { VGLUT1- } \\
\text { 2xmOrange2 }\end{array}$ & $\begin{array}{l}\text { Glutamate } \\
\text { transporter } 1\end{array}$ & $\mathrm{~b}$ & Rat hippocampal neurons & Micro & {$[23]$} \\
\hline $\begin{array}{l}\text { Synaptic } \\
\text { vesicles }\end{array}$ & vGluTpH & $\begin{array}{l}\text { Glutamate } \\
\text { transporter } 1\end{array}$ & $\mathrm{~b}$ & Rat hippocampal neurons & Micro & {$[24]$} \\
\hline $\begin{array}{l}\text { Synaptic } \\
\text { vesicles }\end{array}$ & vGluT-pHl & $\begin{array}{l}\text { Glutamate } \\
\text { transporter } 1\end{array}$ & $\mathrm{~b}$ & $\begin{array}{c}\text { Mouse hippocampal } \\
\text { neurons }\end{array}$ & Micro & {$[66]$} \\
\hline $\begin{array}{l}\text { Synaptic } \\
\text { vesicles }\end{array}$ & syp-pHl & Synaptophysin 1 & $\mathrm{~b}$ & $\begin{array}{c}\text { Mouse hippocampal } \\
\text { neurons }\end{array}$ & Micro & {$[66]$} \\
\hline $\begin{array}{l}\text { PTH1R } \\
\text { containing } \\
\text { vesicles }\end{array}$ & hPTH1R-pHluorin2 & $\begin{array}{l}\text { human parathyroid } \\
\text { hormone } 1 \text { receptor }\end{array}$ & $\mathrm{b}$ & HEK293 cells & Micro & {$[30]$} \\
\hline $\begin{array}{l}\text { Secretory } \\
\text { garnules }\end{array}$ & CgA-ECFP & Chromogranin B & $\begin{array}{l}5 . \\
5\end{array}$ & PC12 cells & FLIM & [69] \\
\hline $\begin{array}{l}\text { Vesicles/ } \\
\text { endoplasmic } \\
\text { reticulum }\end{array}$ & pHluron-GluR-D & $\begin{array}{l}\text { signal peptide- } \\
\text { pHluorin-glutamate } \\
\text { receptor }\end{array}$ & $\mathrm{b}$ & Rat hippocampal neurons & Micro & {$[56]$} \\
\hline $\begin{array}{l}\text { Insulin } \\
\text { secretory } \\
\text { granules }\end{array}$ & Phogrin-pHluorin & $\begin{array}{l}\text { Signal peptide- } \\
\text { pHluorin-phogrin }\end{array}$ & $\mathrm{b}$ & MIN6 cells & Micro & {$[68]$} \\
\hline $\begin{array}{c}\text { Insulin } \\
\text { secretory } \\
\text { granules }\end{array}$ & Insulin-pHluorin & Prepro-insulin & $\mathrm{b}$ & MIN6 cells & Micro & {$[68]$} \\
\hline
\end{tabular}


Table 6. Cont.

\begin{tabular}{|c|c|c|c|c|c|c|}
\hline & Sensor & Tag & pH & Organism/Cell Type & Instrument $^{\mathrm{a}}$ & Reference \\
\hline $\begin{array}{l}\text { Large dense- } \\
\text { core vesicles } \\
\text { LDCV }\end{array}$ & $\begin{array}{c}\text { NPY- } \\
\text { ClopHensor }\end{array}$ & $\begin{array}{l}\text { Neuropeptide } \mathrm{Y}, \mathrm{N}- \\
\text { terminal signal }\end{array}$ & $5.2,5.6$ & PC12, WSS- 1 cells & Micro & [45] \\
\hline $\begin{array}{c}\text { Early } \\
\text { endosomes }\end{array}$ & $\begin{array}{l}\text { Cellubrevin-r- } \\
\text { pHluorin }\end{array}$ & Cellubrevin & 5.9 & HEK cells & Micro & [59] \\
\hline Endosomes & Tat-E ${ }^{1}$ GFP & $\begin{array}{c}\text { Transactivator } \\
\text { protein of human } \\
\text { immunodeficiency } \\
\text { virus-1 }\end{array}$ & $\begin{array}{c}6.8 \text { early/ } \\
5.8-6.5\end{array}$ & HeLa cells & Micro & {$[50]$} \\
\hline $\begin{array}{l}\text { Multivesic } \\
\text { ular bodies }\end{array}$ & PRpHluorin-AtVSR2 & $\begin{array}{l}\text { Vacuolar-sorting } \\
\text { receptor } 2\end{array}$ & 6.2 & A. thaliana & Micro & [4] \\
\hline Vacuoles & aleurain-PRpHluorin & Aleurain & 5.2 & A. thaliana & Micro & [4] \\
\hline Vacuoles & $\mathrm{RaVC}$ & & $6.2-6.5$ & A. niger & Micro & [33] \\
\hline
\end{tabular}

a Micro, FLIM, spec, flow stand for microscopy, fluorescence life time microscopy, spectrophotometry and flow cytometry; ${ }^{\mathrm{b}}$ Only $\mathrm{pH}$ changes are presented in the paper.

Table 7. Select examples of $\mathrm{pH}$-sensitive FPs targeted to peroxisomes, mitochondria, and other specialized compartments.

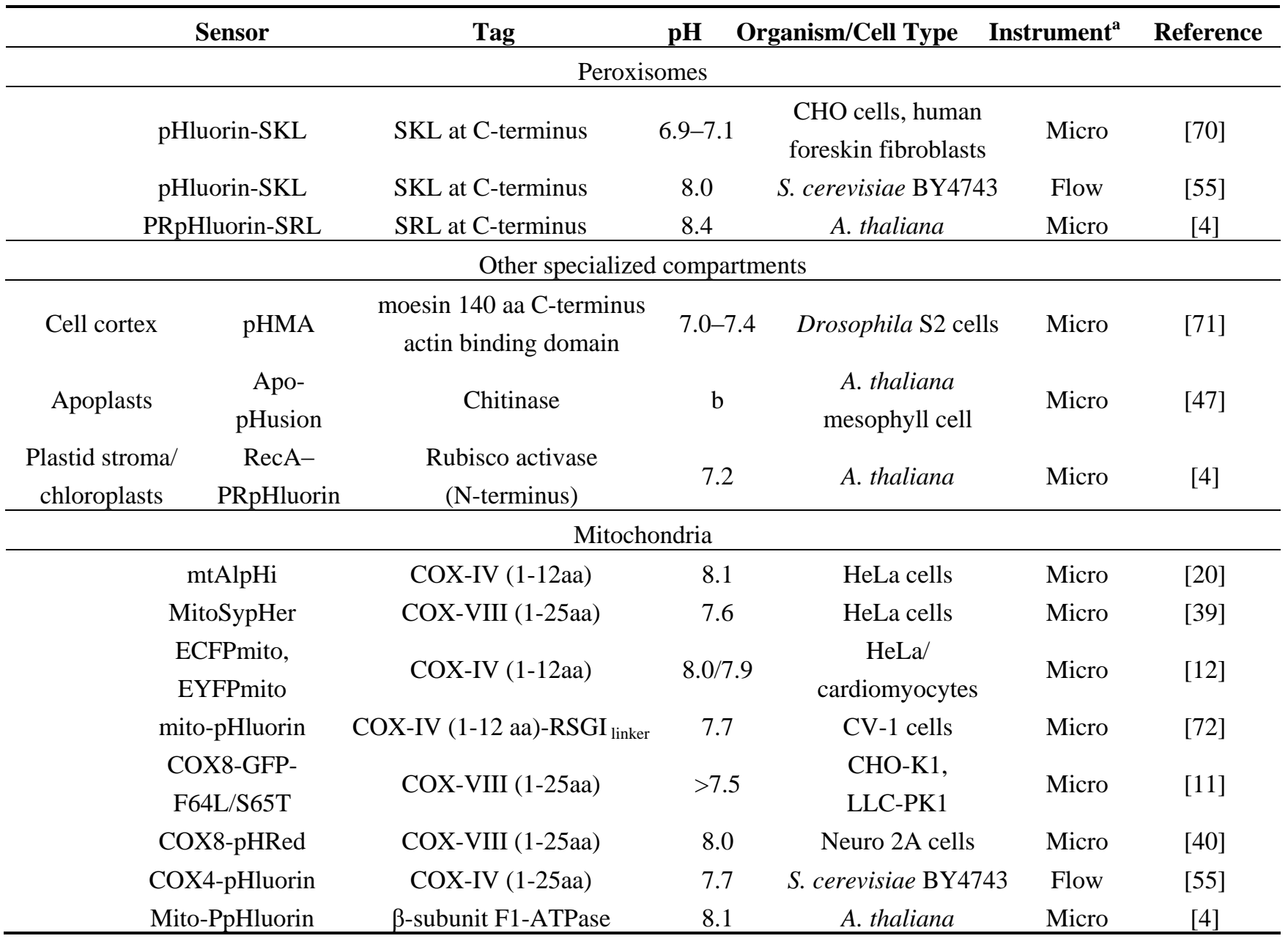

a Micro, FLIM, spec, flow stand for microscopy, fluorescence life time microscopy, spectrophotometry and flow cytometry; ${ }^{\mathrm{b}}$ Only $\mathrm{pH}$ changes are presented in the paper. 
Peroxisomes [73], organelles that derived from endoplasmic reticulum, are involved in many different cellular functions, such as breakdown of fatty acids, polyamines and D-amino acids. r-pHluorin is directed to peroxisomes with peroxisomal targeting SKL/SRL peptide, and is used to measure peroxisomal $\mathrm{pH}$, which range from 6.9 to 8.4 [4,55,70] (Table 7). A chitinase and an $\mathrm{N}$-terminus of Rubisco activase (recA) protein fused to pHusion and PRpHluorin directed chimeric proteins to apoplasts and plastid stroma of Arabidopsis thaliana, respectively [4,47]. The $\mathrm{pH}$ of the cell cortex of Drosophila S2 cells was analyzed using pHMA sensor-pHluorin tagged to moesin [71].

Recent studies on mitochondrial $\mathrm{pH}$ present a good demonstration of the importance of the selection of a $\mathrm{pH}$ sensor that matches the $\mathrm{pH}$ of the subcellular compartment [74] (Table 7). The resting mitochondrial matrix $\mathrm{pH}\left(\mathrm{pH}_{\mathrm{M}}\right)$ is markedly alkaline from 7.6 to $8.1[4,11,12,20,40,41,55,72]$. Previously, the $\mathrm{pH}$ sensors pHluorin, ECFP, EYFP, and ECFP with a $\mathrm{pK}_{\mathrm{a}}$ of approximately 7 have been used to measure $\mathrm{pH}_{\mathrm{M}}[11-13,74]$. These sensors are insensitive to small $\mathrm{pH}$ changes at $\mathrm{pH}_{\mathrm{M}}$; therefore, $\mathrm{pH}_{\mathrm{M}}$ dynamics are easily missed. Recent improvements in live cell fluorescence imaging have revealed that proton concentration rapidly fluctuates within individual mitochondria, as determined using mitoSypHer $[39,75]$. The $\mathrm{pK}_{\mathrm{a}}$ of ratiometric mitoSypHer is approximately 8 , which is similar to the $\mathrm{pK}_{\mathrm{a}}$ of ratiometric pHRed [40] and intensity-based mtAlpHi [20] and pHTomato [24]—all of which are well-suited for $\mathrm{pH}_{\mathrm{M}}$ measurements.

\section{Instrumentation}

The intrinsic $\mathrm{pH}$ of studied subcellular compartments and the type of available equipment determine the selection of FPs for live cell imaging. Intensity-based $\mathrm{pH}$ sensors require a collection of data at one wavelength; therefore, rather basic equipment is necessary for one-wavelength intensity measurements. Conversely, a collection of fluorescence at two wavelengths is necessary for dual emission $\mathrm{pH}$ sensors; thus, instruments with multiple detectors and filters are needed. Dual excitation sensors, like ratiometric pHluorins, are analyzed with advanced equipment with two excitation sources. Moreover, the spatial analysis of $\mathrm{pH}$ within organelles is greatly benefitted with equipment that has a good resolution in Z-direction. Therefore, confocal microscopy is favored over wide-field fluorescent microscopy. The recent developments of highly effective imaging setups with improved resolution and speed, as well as supercontinuum laser have greatly improved the detection of $\mathrm{pH}$ in cultured cells and living organisms.

A traditional fluorescence spectroscopy is the most extensively applied technique for analyzing the $\mathrm{pH}_{\mathrm{i}}$ of yeast when pHluorin is used as a $\mathrm{pH}$ sensor [51-54]. Although spectroscopy rapidly records the average $\mathrm{pH}_{\mathrm{i}}$ of a population, it provides insufficient single-cell information.

On the other hand, single-cell analysis offers more detailed insight into population variability, thereby facilitating a considerably deeper understanding of cell physiology. To obtain spatial distribution and a detailed mapping of the $\mathrm{pH}$ in single cells, researchers have used $\mathrm{pH}$-sensitive FPs in combination with fluorescence microscopy (Figure 3). Despite the advantages of this approach, the primary drawback of this technique is the need to post-process images for evaluating subpopulation content. Nonetheless, the development of confocal microscopy revolutionized biological sciences and provided great tools for cellular imaging on a subcellular level. Thus, confocal microscopy with 
excellent resolution (xy $0.2-0.5 \mu \mathrm{m}$ and $\mathrm{z} \quad 0.6-1.5 \mu \mathrm{m}$ ) provides a very effective way to obtain high-resolution $\mathrm{pH}$ maps.

Figure 3. (A) A set up of dual excitation sequential scanning confocal microscope for imaging ratiometric pHluorin probes. (B) Fluorescence excitation spectra of pHluorin in buffers with $\mathrm{pH}$ ranging from 5.2 to 8.5. (C) A hypothetical pHluorin dose reponse curve; a plot of fluorescence ratio versus $\mathrm{pH}$. The ratios between the emission intensities at 405- and 476-nm are calculated. The physiological target $\mathrm{pH}$ range and physiologically relevant dynamic range are indicated. (D) Pseudocolored image (right) of permeabilized yeast cells in buffered solution with nigericin is calculated from images taken at 405- and 476-nm excitation (Scans 1 and 2). Different colors are assigned to defined $\mathrm{pH}$ values in accordance with the in situ calibration curve (blue, alkalinic; red, acidic). The in situ calibration curve is shown in panel D.

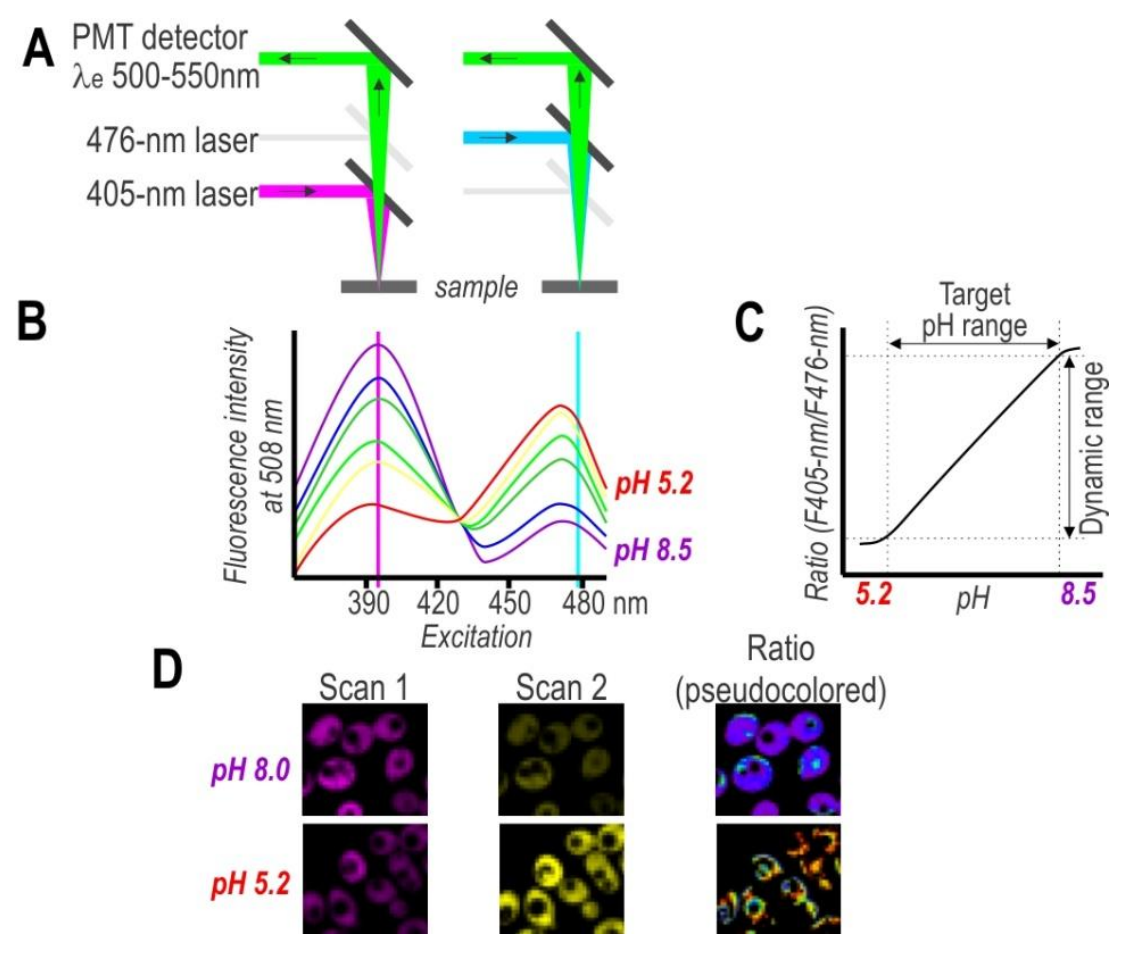

Historically, equipment dictated the evolution of fluorescent dyes and FPs. Therefore, cyan, green, and yellow FPs whose excitations correspond to the emission lines of the most widespread Argon laser are best studied (Table 1). Subsequently, microscopes equipped with violet and red laser along with Argon laser promoted the evolution of red- and far red-shifted FPs, as well as ratiometric pH sensors by excitation (Table 2). Advanced confocal microscopes equipped with multiple independent detectors permit simultaneous collection of several fluorescence signals, which agrees with ratiometric sensors by emission (deGFP [35], E ${ }^{\mathrm{n}}$ GFP [36,37], Wt-CoGFP [38], and pHusion [47]) and multicolor labeling. Multiphoton microscopy in cases of low photo-toxicity and photo-bleaching is an alternative to single-photon excitation confocal microscopy. The deGFPs and $\mathrm{E}^{\mathrm{n}} \mathrm{GFPs}$ have the potential of two-photon ratiometric indicators [35-37,48]. Further, fluorescence life time microscopy (FLIM) offers an alternative solution for life cell imaging. pHRed [40] and ECPF [69] exhibit a pH-dependent fluorescence lifetime that can be used to image intracellular $\mathrm{pH}$. 
A good alternative to spectroscopy and microscopy is flow cytometry, which combines rapid high-throughput, analysis, and acquisition of multiparameter results at the single-cell level for each cell in a population. For the dual excitation of all pHluorin-based ratiometric $\mathrm{pH}$ probes, a flow cytometer equipped with split optics for 405- and 488-nm light paths is necessary [31,55] (Figure 4). After excitation with 488-nm and 405-nm laser light, green fluorescence is detected in separate channels, and the ratios of two fluorescence parameters (i.e., F405-nm and F488-nm) are calculated for every cell by dividing the emission signals. Finally, to correlate ratios with $\mathrm{pH}$, a calibration curve that links fluorescence intensity ratios to $\mathrm{pH}$ is generated.

Figure 4. Flow cytometry for high-throughput analysis of cytosolic $\mathrm{pH}$ in cells expressing ratiometric $\mathrm{pH}$ sensors by excitation [31]. (A) The light paths of excitation at 405 and $488 \mathrm{~nm}$ and the emission optics are illustrated. Fluorescence intensity data are depicted for both detection channels - F(488 nm) and F(405 nm). (B) A 2D dot plot of F405-nm versus F488-nm shows grouped fluorescence signals. (C) The ratio of the fluorescence intensities of $\mathrm{F}(405 \mathrm{~nm}) / \mathrm{F}(488 \mathrm{~nm})$ plotted as the ratio height signal generates a narrow peak. (D) An overlay of $2 \mathrm{D}$ dot plots of $\mathrm{F}(405 \mathrm{~nm})$ versus $\mathrm{F}(488 \mathrm{~nm})$ for $\mathrm{pH}$ sensor at indicated $\mathrm{pH}$ values. (E) An overlay of ratios of the fluorescence intensities of $\mathrm{F}(405 \mathrm{~nm}) / \mathrm{F}(488 \mathrm{~nm})$ depicted from (F). Note: In less than 2 min, the fluorescence signals of 50,000 cells can be analyzed and post-processed.
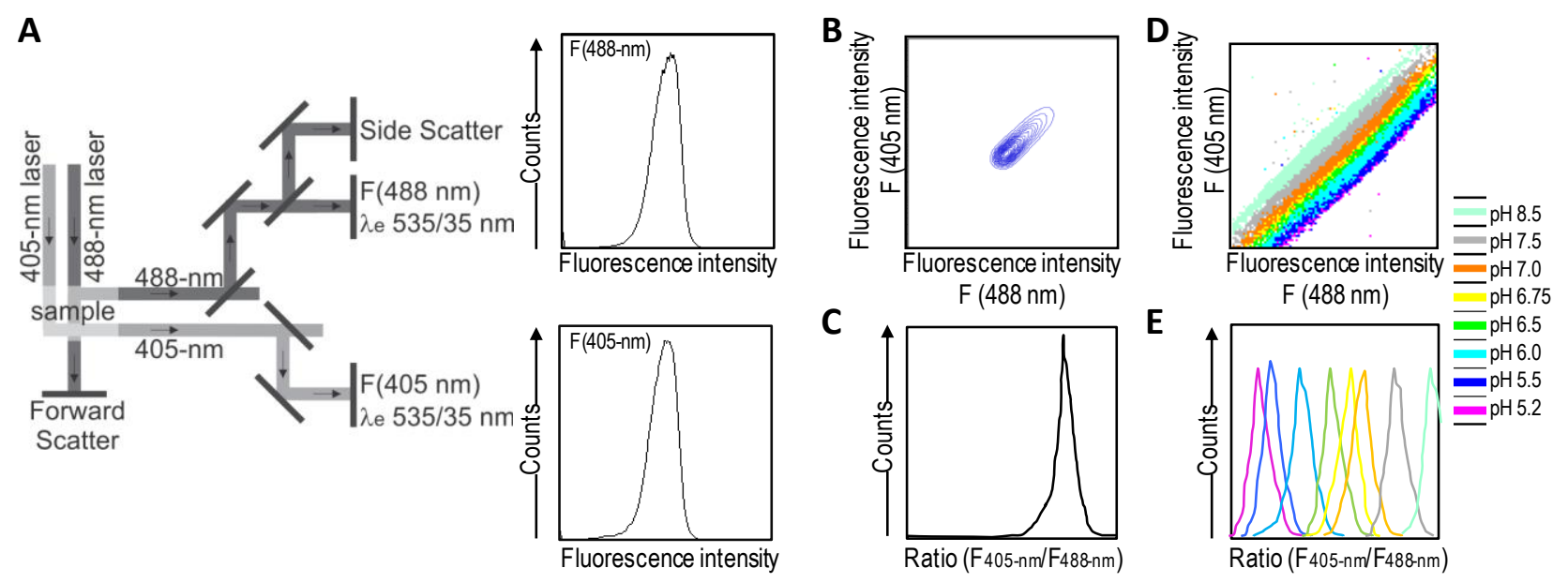

Ratiometric flow cytometry goes beyond microscopy for high-throughput analysis and screening with automatic post-processing of obtained data. Conversely, it does not permit the monitoring of particular individual cells over time, thereby making it a complementary solution rather than a replacement for microscopy techniques.

\section{Conclusions}

Undoubtedly, the maintenance of an appropriate $\mathrm{pH}$ within individual membrane-enclosed compartments is important for normal physiology of the cell and organelles. Over the previous decade, considerable progress has been made in understanding the $\mathrm{pH}$ regulatory mechanisms of the cell that progress in tandem with recent developments of highly effective imaging setups and genetically encoded $\mathrm{pH}$-sensitive fluorescent sensors. In merely fifteen years, we have witnessed an expansion in 
genetically encoded $\mathrm{pH}$-sensitive fluorescent proteins. $\mathrm{pH}$ sensors span almost the entire visible spectrum from green to red and with $\mathrm{pK}_{\mathrm{a}}$ that extends over the entire physiological $\mathrm{pH}$ range. Most modern FPs have been modified by random and/or iterative mutagenesis to optimize, improve, or enhance fluorescence characteristics and their stability as proteins. The sensors for virtually any subcellular location have been engineered from only a few building blocks. The interplay of sophisticated imaging techniques and transgene $\mathrm{pH}$ sensors has provided a very effective method for obtaining spatial and temporal high-resolution $\mathrm{pH}$ maps and the ability to monitor signaling dynamics on single-cell and subcellular levels.

In this review, we have described $\mathrm{pH}$-sensitive fluorescent proteins that we consider to be useful or as having potential for generating novel sensors for live cell applications. The trend in the evolution of $\mathrm{pH}$ sensors is oriented toward generating brighter, photostable yellow and red ratiometric FPs to limit the cell damage that might be caused by the illumination of the fluorophore. Advances have been made for $\mathrm{pH}$-sensitive FPs with narrow excitation and emission peaks to suit multicolor labeling. The narrow spectral peaks minimize the crosstalk between fluorophores, thereby providing more accurate results in multicolor analysis. With regard to developments in equipment, $\mathrm{pH}$ sensors that are suited for fluorescence lifetime microscopy and two-photon laser scanning fluorescence microscopy have been engineered. Transgene $\mathrm{pH}$ sensors are already changing the boundaries of our understanding of in vivo cellular $\mathrm{pH}$ dynamics at scales from the subcellular to the entire organism. Further, $\mathrm{pH}$-sensitive FPs expressed in the cell and subcellular compartments provide the most physiologically relevant information on the spatial and temporal behavior of $\mathrm{pH}$ homeostasis. Overall, we anticipate that this overview will help in deciding which $\mathrm{pH}$-sensitive fluorescent protein should be selected for forthcoming cellular imaging experiments, and how the selected $\mathrm{pH}$ sensor could be applied to obtain accurate answers to various questions in this regard.

\section{Acknowledgments}

This research was supported by the Slovenian Research Agency and EN-FIST, Centre of Excellence.

\section{Conflicts of Interest}

The author declares no conflict of interest.

\section{References}

1. Casey, J.R.; Grinstein, S.; Orlowski, J. Sensors and regulators of intracellular pH. Nat. Rev. Mol. Cell Biol. 2010, 11, 50-61.

2. Benčina, M.; Bagar, T.; Lah, L.; Kraševec, N. A comparative genomic analysis of calcium and proton signaling/homeostasis in Aspergillus species. Fungal Genet. Biol. 2009, 46, S93-S104.

3. Orij, R.; Brul, S.; Smits, G.J. Intracellular $\mathrm{pH}$ is a tightly controlled signal in yeast. Biochim. Biophys. Acta. 2011, 1810, 933-944.

4. Shen, J.; Zeng, Y.; Zhuang, X.; Sun, L.; Yao, X.; Pimpl, P.; Jiang, L. Organelle pH in the arabidopsis endomembrane system. Mol. Plant 2013, 6, 1419-1437. 
5. Day, R.N.; Davidson, M.W. The fluorescent protein palette: Tools for cellular imaging. Chem. Soc. Rev. 2009, 38, 2887-2921.

6. Prasher, D.C.; Eckenrode, V.K.; Ward, W.W.; Prendergast, F.G.; Cormier, M.J. Primary structure of the Aequorea victoria green-fluorescent protein. Gene 1992, 111, 229-233.

7. Brejc, K.; Sixma, T.K.; Kitts, P.A.; Kain, S.R.; Tsien, R.Y.; Ormö, M.; Remington, S.J. Structural basis for dual excitation and photoisomerization of the Aequorea victoria green fluorescent protein. Proc. Natl. Acad. Sci. USA 1997, 94, 2306-2311.

8. Scharnagl, C.; Raupp-Kossmann, R.; Fischer, S.F. Molecular basis for $\mathrm{pH}$ sensitivity and proton transfer in green fluorescent protein: Protonation and conformational substates from electrostatic calculations. Biophys. J. 1999, 77, 1839-1857.

9. Bizzarri, R.; Serresi, M.; Luin, S.; Beltram, F. Green fluorescent protein based pH indicators for in vivo use: A review. Anal. Bioanal. Chem. 2009, 393, 1107-1122.

10. Shcherbakova, D.M.; Subach, O.M.; Verkhusha, V.V. Red fluorescent proteins: Advanced imaging applications and future design. Angew. Chem. 2012, 51, 10724-10738.

11. Kneen, M.; Farinas, J.; Li, Y.; Verkman, A.S. Green fluorescent protein as a noninvasive intracellular pH indicator. Biophys. J. 1998, 74, 1591-1599.

12. Llopis, J.; McCaffery, J.M.; Miyawaki, A.; Farquhar, M.G.; Tsien, R.Y. Measurement of cytosolic, mitochondrial, and Golgi $\mathrm{pH}$ in single living cells with green fluorescent proteins. Proc. Natl. Acad. Sci. USA 1998, 95, 6803-6808.

13. Miesenböck, G.; de Angelis, D.A.; Rothman, J.E. Visualizing secretion and synaptic transmission with pH-sensitive green fluorescent proteins. Nature 1998, 394, 192-195.

14. Sankaranarayanan, S.; de Angelis, D.; Rothman, J.E.; Ryan, T.A. The use of pHluorins for optical measurements of presynaptic activity. Biophys. J. 2000, 79, 2199-2208.

15. Moseyko, N.; Feldman, L.J. Expression of $\mathrm{pH}$-sensitive green fluorescent protein in Arabidopsis thaliana. Plant Cell Environ. 2001, 24, 557-563.

16. Ai, H.-W.; Olenych, S.G.; Wong, P.; Davidson, M.W.; Campbell, R.E. Hue-shifted monomeric variants of Clavularia cyan fluorescent protein: Identification of the molecular determinants of color and applications in fluorescence imaging. BMC Biol. 2008, 6, 13.

17. Wachter, R.M.; Elsliger, M.A.; Kallio, K.; Hanson, G.T.; Remington, S.J. Structural basis of spectral shifts in the yellow-emission variants of green fluorescent protein. Structure 1998, 6, 1267-1277.

18. Griesbeck, O.; Baird, G.S.; Campbell, R.E.; Zacharias, D.A.; Tsien, R.Y. Reducing the environmental sensitivity of yellow fluorescent protein. Mechanism and applications. J. Biol. Chem. 2001, 276, 29188-29194.

19. Miyawaki, A.; Griesbeck, O.; Heim, R.; Tsien, R.Y. Dynamic and quantitative $\mathrm{Ca}^{2+}$ measurements using improved cameleons. Proc. Natl. Acad. Sci. USA 1999, 96, 2135-2140.

20. Abad, M.F.C.; Di Benedetto, G.; Magalhães, P.J.; Filippin, L.; Pozzan, T. Mitochondrial pH monitored by a new engineered green fluorescent protein mutant. J. Biol. Chem. 2004, 279, 11521-11529.

21. Lam, A.J.; St-Pierre, F.; Gong, Y.; Marshall, J.D.; Cranfill, P.J.; Baird, M.A.; McKeown, M.R.; Wiedenmann, J.; Davidson, M.W.; Schnitzer, M.J.; et al. Improving FRET dynamic range with bright green and red fluorescent proteins. Nat. Methods 2012, 9, 1005-1012. 
22. Shaner, N.C.; Lin, M.Z.; McKeown, M.R.; Steinbach, P.A.; Hazelwood, K.L.; Davidson, M.W.; Tsien, R.Y. Improving the photostability of bright monomeric orange and red fluorescent proteins. Nat. Methods 2008, 5, 545-551.

23. Li, H.; Foss, S.M.; Dobryy, Y.L.; Park, C.K.; Hires, S.A.; Shaner, N.C.; Tsien, R.Y.; Osborne, L.C.; Voglmaier, S.M. Concurrent imaging of synaptic vesicle recycling and calcium dynamics. Front. Mol. Neurosci. 2011, 4, 34.

24. Li, Y.; Tsien, R.W. pHTomato, a red, genetically encoded indicator that enables multiplex interrogation of synaptic activity. Nat. Neurosci. 2012, 15, 1047-1053.

25. Johnson, D.E.; Ai, H.-W.; Wong, P.; Young, J.D.; Campbell, R.E.; Casey, J.R. Red fluorescent protein $\mathrm{pH}$ biosensor to detect concentrative nucleoside transport. J. Biol. Chem. 2009, 284, 20499-20511.

26. Shcherbo, D.; Murphy, C.S.; Ermakova, G.V; Solovieva, E.A.; Chepurnykh, T.V; Shcheglov, A.S.; Verkhusha, V.V; Pletnev, V.Z.; Hazelwood, K.L.; Roche, P.M.; et al. Far-red fluorescent tags for protein imaging in living tissues. Biochem. J. 2009, 418, 567-574.

27. Shaner, N.C.; Campbell, R.E.; Steinbach, P.A.; Giepmans, B.N.G.; Palmer, A.E.; Tsien, R.Y. Improved monomeric red, orange and yellow fluorescent proteins derived from Discosoma sp. red fluorescent protein. Nat. Biotechnol. 2004, 22, 1567-1572.

28. Scott, C.C.; Gruenberg, J. Ion flux and the function of endosomes and lysosomes: $\mathrm{pH}$ is just the start: The flux of ions across endosomal membranes influences endosome function not only through regulation of the luminal pH. BioEssays 2011, 33, 103-110.

29. Ohgaki, R.; van IJzendoorn, S.C.D.; Matsushita, M.; Hoekstra, D.; Kanazawa, H. Organellar $\mathrm{Na}^{+} / \mathrm{H}^{+}$exchangers: Novel players in organelle $\mathrm{pH}$ regulation and their emerging functions. Biochemistry 2011, 50, 443-450.

30. Mahon, M.J. pHluorin2: An enhanced, ratiometric, $\mathrm{pH}$-sensitive green florescent protein. Adv. Biosci. Biotechnol. 2011, 2, 132-137.

31. Valkonen, M.; Mojzita, D.; Penttilä, M.; Benčina, M. Noninvasive high-throughput single-cell analysis of the intracellular $\mathrm{pH}$ of saccharomyces cerevisiae by ratiometric flow cytometry. Appl. Environ. Microbiol. 2013, 79, 7179-7187.

32. Morimoto, Y.V; Kojima, S.; Namba, K.; Minamino, T. M153R mutation in a pH-sensitive green fluorescent protein stabilizes its fusion proteins. PLoS One 2011, 6, e19598.

33. Bagar, T.; Altenbach, K.; Read, N.D.; Benčina, M. Live-cell imaging and measurement of intracellular $\mathrm{pH}$ in filamentous fungi using a genetically encoded ratiometric probe. Eukaryot. Cell 2009, 8, 703-712.

34. Bagar, T.; Benčina, M. Antiarrhythmic drug amiodarone displays antifungal activity, induces irregular calcium response and intracellular acidification of Aspergillus niger - amiodarone targets calcium and $\mathrm{pH}$ homeostasis of A. niger. Fungal Genet. Biol. 2012, 49, 779-791.

35. Hanson, G.T.; McAnaney, T.B.; Park, E.S.; Rendell, M.E.P.; Yarbrough, D.K.; Chu, S.; Xi, L.; Boxer, S.G.; Montrose, M.H.; Remington, S.J. Green fluorescent protein variants as ratiometric dual emission $\mathrm{pH}$ sensors. 1. Structural characterization and preliminary application. Biochemistry 2002, 41, 15477-15488. 
36. Bizzarri, R.; Arcangeli, C.; Arosio, D.; Ricci, F.; Faraci, P.; Cardarelli, F.; Beltram, F. Development of a novel GFP-based ratiometric excitation and emission $\mathrm{pH}$ indicator for intracellular studies. Biophys. J. 2006, 90, 3300-3314.

37. Bizzarri, R.; Nifosì, R.; Abbruzzetti, S.; Rocchia, W.; Guidi, S.; Arosio, D.; Garau, G.; Campanini, B.; Grandi, E.; Ricci, F.; et al. Green fluorescent protein ground states: The influence of a second protonation site near the chromophore. Biochemistry 2007, 46, 5494-5504.

38. Ogoh, K.; Kinebuchi, T.; Murai, M.; Takahashi, T.; Ohmiya, Y.; Suzuki, H. Dual-color-emitting green fluorescent protein from the sea cactus Cavernularia obesa and its use as a $\mathrm{pH}$ indicator for fluorescence microscopy. Lumin 2013, 28, 582-591.

39. Schulte, A.; Lorenzen, I.; Böttcher, M.; Plieth, C. A novel fluorescent $\mathrm{pH}$ probe for expression in plants. Plant Methods 2006, $2,7$.

40. Tantama, M.; Hung, Y.P.; Yellen, G. Imaging intracellular pH in live cells with a genetically encoded red fluorescent protein sensor. J. Am. Chem. Soc. 2011, 133, 10034-10037.

41. Poburko, D.; Santo-Domingo, J.; Demaurex, N. Dynamic regulation of the mitochondrial proton gradient during cytosolic calcium elevations. J. Biol. Chem. 2011, 286, 11672-11684.

42. Belousov, V.V.; Fradkov, A.F.; Lukyanov, K.A.; Staroverov, D.B.; Shakhbazov, K.S.; Terskikh, A.V.; Lukyanov, S. Genetically encoded fluorescent indicator for intracellular hydrogen peroxide. Nat. Methods 2006, 3, 281-286.

43. Awaji, T.; Hirasawa, A.; Shirakawa, H.; Tsujimoto, G.; Miyazaki, S. Novel green fluorescent protein-based ratiometric indicators for monitoring $\mathrm{pH}$ in defined intracellular microdomains. Biochem. Biophys. Res. Commun. 2001, 289, 457-462.

44. Chandy, G.; Grabe, M.; Moore, H.P.; Machen, T.E. Proton leak and CFTR in regulation of Golgi pH in respiratory epithelial cells. Am. J. Physiol. 2001, 281, C908-C921.

45. Arosio, D.; Ricci, F.; Marchetti, L.; Gualdani, R.; Albertazzi, L.; Beltram, F. Simultaneous intracellular chloride and $\mathrm{pH}$ measurements using a GFP-based sensor. Nat. Methods 2010, 7, 516-518.

46. Mukhtarov, M.; Liguori, L.; Waseem, T.; Rocca, F.; Buldakova, S.; Arosio, D.; Bregestovski, P. Calibration and functional analysis of three genetically encoded $\mathrm{Cl}(-) / \mathrm{pH}$ sensors. Front. Mol. Neurosci. 2013, 6, 9 .

47. Gjetting, K.S.K.; Ytting, C.K.; Schulz, A.; Fuglsang, A.T. Live imaging of intra- and extracellular $\mathrm{pH}$ in plants using pHusion, a novel genetically encoded biosensor. J. Exp. Bot. 2012, 63, 3207-3218.

48. Raimondo, J.V.; Irkle, A.; Wefelmeyer, W.; Newey, S.E.; Akerman, C.J. Genetically encoded proton sensors reveal activity-dependent $\mathrm{pH}$ changes in neurons. Front. Mol. Neurosci. 2012, 5, $1-12$.

49. Karagiannis, J.; Young, P.G. Intracellular $\mathrm{pH}$ homeostasis during cell-cycle progression and growth state transition in Schizosaccharomyces pombe. J. Cell Sci. 2001, 114, 2929-2941.

50. Serresi, M.; Bizzarri, R.; Cardarelli, F.; Beltram, F. Real-time measurement of endosomal acidification by a novel genetically encoded biosensor. Anal. Bioanal. Chem. 2009, 393, 1123-1133.

51. Ullah, A.; Lopes, M.I.; Brul, S.; Smits, G.J. Intracellular pH homeostasis in Candida glabrata in infection-associated conditions. Microbiology 2013, 159, 803-813. 
52. Maresová, L.; Hosková, B.; Urbánková, E.; Chaloupka, R.; Sychrová, H. New applications of pHluorin-measuring intracellular $\mathrm{pH}$ of prototrophic yeasts and determining changes in the buffering capacity of strains with affected potassium homeostasis. Yeast 2010, 27, 317-325.

53. Orij, R.; Postmus, J.; Ter Beek, A.; Brul, S.; Smits, G.J. In vivo measurement of cytosolic and mitochondrial $\mathrm{pH}$ using a $\mathrm{pH}$-sensitive GFP derivative in Saccharomyces cerevisiae reveals a relation between intracellular $\mathrm{pH}$ and growth. Microbiology 2009, 155, 268-278.

54. Martínez-Muñoz, G.A.; Kane, P. Vacuolar and plasma membrane proton pumps collaborate to achieve cytosolic pH homeostasis in yeast. J. Biol. Chem.2008, 283, 20309-20319.

55. Ayer, A.; Sanwald, J.; Pillay, B.A.; Meyer, A.J.; Perrone, G.G.; Dawes, I.W. Distinct redox regulation in sub-cellular compartments in response to various stress conditions in Saccharomyces cerevisiae. PLoS One 2013, 8, doi: 10.1371/journal.pone.0065240.

56. Khiroug, S.S.; Pryazhnikov, E.; Coleman, S.K.; Jeromin, A.; Keinänen, K.; Khiroug, L. Dynamic visualization of membrane-inserted fraction of pHluorin-tagged channels using repetitive acidification technique. BMC Neurosci. 2009, 10, 141.

57. Rivinoja, A.; Kokkonen, N.; Kellokumpu, I.; Kellokumpu, S. Elevated Golgi pH in breast and colorectal cancer cells correlates with the expression of oncofetal carbohydrate T-antigen. J. Cell. Physiol. 2006, 208, 167-174.

58. Storrie, B. Maintenance of Golgi apparatus structure in the face of continuous protein recycling to the endoplasmic reticulum: Making ends meet. Int. Rev. Cytol. 2005, 244, 69-94.

59. Disbrow, G.L.; Hanover, J.A.; Schlegel, R. Endoplasmic reticulum-localized human papillomavirus type 16 E5 protein alters endosomal pH but not trans-Golgi pH. J. Virol. 2005, 79, 5839-5846.

60. Starr, T.; Forsten-Williams, K.; Storrie, B. Both post-Golgi and intra-Golgi cycling affect the distribution of the Golgi phosphoprotein GPP130. Traffic 2007, 8, 1265-1279.

61. Lázaro-Diéguez, F.; Jiménez, N.; Barth, H.; Koster, A.J.; Renau-Piqueras, J.; Llopis, J.L.; Burger, K.N.J.; Egea, G. Actin filaments are involved in the maintenance of Golgi cisternae morphology and intra-Golgi pH. Cell Motil. Cytoskelet. 2006, 63, 778-791.

62. Liu, D.; Martina, J.A.; Wu, X.S.; Hammer, J.A.; Long, E.O. Two modes of lytic granule fusion during degranulation by natural killer cells. Immunol. Cell Biol. 2011, 89, 728-738.

63. Dean, C.; Liu, H.; Dunning, F.M.; Chang, P.Y.; Jackson, M.B.; Chapman, E.R. Synaptotagmin-IV modulates synaptic function and long-term potentiation by regulating BDNF release. Nat. Neurosci. 2009, 12, 767-776.

64. Sankaranarayanan, S.; Ryan, T.A. Real-time measurements of vesicle-SNARE recycling in synapses of the central nervous system. Nat. Cell Biol. 2000, 2, 197-204.

65. Voglmaier, S.M.; Kam, K.; Yang, H.; Fortin, D.L.; Hua, Z.; Nicoll, R.A.; Edwards, R.H. Distinct endocytic pathways control the rate and extent of synaptic vesicle protein recycling. Neuron 2006, 51,71-84.

66. Sinha, R.; Ahmed, S.; Jahn, R.; Klingauf, J. Two synaptobrevin molecules are sufficient for vesicle fusion in central nervous system synapses. Proc. Natl. Acad. Sci. USA 2011, 108, 14318-14323.

67. Dean, C.; Dunning, F.M.; Liu, H.; Bomba-Warczak, E.; Martens, H.; Bharat, V.; Ahmed, S.; Chapman, E.R. Axonal and dendritic synaptotagmin isoforms revealed by a pHluorin-syt functional screen. Mol. Biol. Cell 2012, 23, 1715-1727. 
68. Ohara-Imaizumi, M.; Nakamichi, Y.; Tanaka, T.; Katsuta, H.; Ishida, H.; Nagamatsu, S. Monitoring of exocytosis and endocytosis of insulin secretory granules in the pancreatic beta-cell line MIN6 using pH-sensitive green fluorescent protein (pHluorin) and confocal laser microscopy. Biochem. J. 2002, 363, 73-80.

69. Poëa-Guyon, S.; Pasquier, H.; Mérola, F.; Morel, N.; Erard, M. The enhanced cyan fluorescent protein: A sensitive $\mathrm{pH}$ sensor for fluorescence lifetime imaging. Anal. Bioanal. Chem. 2013, 405, 3983-3987.

70. Jankowski, A.; Kim, J.H.; Collins, R.F.; Daneman, R.; Walton, P.; Grinstein, S. In situ measurements of the $\mathrm{pH}$ of mammalian peroxisomes using the fluorescent protein pHluorin. J. Biol. Chem. 2001, 276, 48748-48753.

71. Fishilevich, E.; Fitzpatrick, J.A.J.; Minden, J.S. pHMA, a pH-sensitive GFP reporter for cell engulfment, in Drosophila embryos, tissues, and cells. Dev. Dyn. 2010, 239, 559-573.

72. Vijayvergiya, C.; De Angelis, D.; Walther, M.; Kühn, H.; Duvoisin, R.M.; Smith, D.H.; Wiedmann, M. High-level expression of rabbit 15-lipoxygenase induces collapse of the mitochondrial pH gradient in cell culture. Biochemistry 2004, 43, 15296-15302.

73. Ast, J.; Stiebler, A.C.; Freitag, J.; Bölker, M. Dual targeting of peroxisomal proteins. Front. Physiol. 2013, 4, 297.

74. Schwarzländer, M.; Murphy, M.P.; Duchen, M.R.; Logan, D.C.; Fricker, M.D.; Halestrap, A.P.; Müller, F.L.; Rizzuto, R.; Dick, T.P.; Meyer, A.J.; et al. Mitochondrial "flashes": A radical concept repHined. Trends Cell Biol. 2012, 22, 503-508.

75. Santo-Domingo, J.; Giacomello, M.; Poburko, D.; Scorrano, L.; Demaurex, N. OPA1 promotes $\mathrm{pH}$ flashes that spread between contiguous mitochondria without matrix protein exchange. EMBO J. 2013, 32, 1927-1940.

(C) 2013 by the authors; licensee MDPI, Basel, Switzerland. This article is an open access article distributed under the terms and conditions of the Creative Commons Attribution license (http://creativecommons.org/licenses/by/3.0/). 